

\title{
Buku Ajar \\ Konsep Pembiayaan Pendidikan Islam
}

\author{
Penulis: \\ Mohamad Rojii \\ Priyo Nurdiyan \\ An'nur Ridwan P \\ Annisa Nur Islamiar \\ Nony Anggraeni \\ Suci Wulandari \\ Dr. Renny Oktafia, M.EI \\ Dr. Hidayatulloh, M.Si.
}

Dr. Eni Fariyatul Fahyuni, M.Pd.I

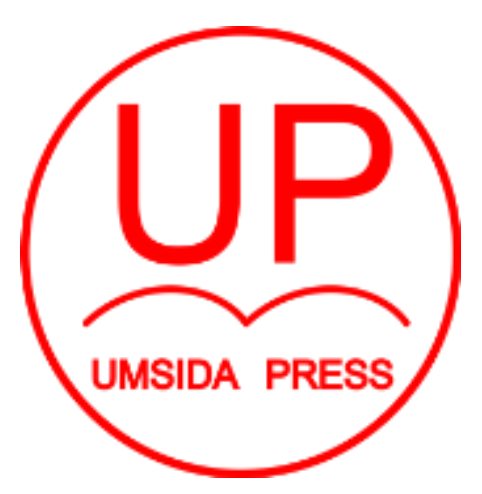

Diterbitkan oleh

UMSIDA PRESS

JI. Mojopahit 666 B Sidoarjo

ISBN: 978-623-7578-66-6

Copyright@2020.

Authors

All rights reserved 


\section{Buku Ajar}

Konsep Pembiayaan Pendidikan Islam

\section{Penulis :}

Mohamad Rojii

Priyo Nurdiyan

An'nur Ridwan P

Annisa Nur Islamiar

Nony Anggraeni

Suci Wulandari

Dr. Renny Oktafia, M.EI

Dr. Hidayatulloh, M.Si.

Dr. Eni Fariyatul Fahyuni, M.Pd.I

ISBN : 978-623-7578-66-6

\section{Editor :}

Dr. Eni Fariyatul Fahyuni, M.Pd.I

Dr. Septi Budi Sartika. M.Pd

\section{Copy Editor :}

Dr. Eni Fariyatul Fahyuni, M.Pd.I

Design Sampul dan Tata Letak :

Dinda Nurrahma A.F.M., S.E.

\section{Penerbit :}

UMSIDA Press

\section{Redaksi :}

Universitas Muhammadiyah Sidoarjo

Jl. Mojopahit No 666B

Sidoarjo, Jawa TImur

Cetakan pertama, Agustus 2020

(C) Hak cipta dilindungi undang-undang

Dilarang memperbanyak karya tulis ini dengan suatu apapun tanpa ijin tertulis dari penerbit. 


\section{KATA PENGANTAR}

Puji syukur kepada Tuhan Yang Maha Esa, sehingga Buku Ajar Konsep Pembiayaan Pendidikan Islam ini dapat disusun dengan baik meskipun perlu penyempurnaan lebih lanjut. Konsep Pembiayaan Pendidikan Islam merupakan mata kuliah Manajemen Pembiayan Pendidikan Islam di Program Studi Magister Manajemen Pendidikan Islam Universitas Muhammadiyah Sidoarjo. Buku ajar Konsep Pembiayaan Pendidikan Islam ini dikhususkan untuk pegangan Mahasiswa Magister Manajemen Pendidikan Islam Universitas Muhammadiyah Sidoarjo.

Pembiayaan pendidikan merupakan salah satu sumber yang sangat berpotensi dalam menentukan sukses dan kelancaran progam pendidikan serta merupakan bagian yang tak terpisahkan dalam manajemen pengelolaan pendidikan. Adapun sistem pembiayaan pendidikan yaitu dimana proses pendapatan dan sumber daya tersedia dan dapat digunakan untuk memformulasikan serta mengoperasionalkan sekolah.

Penulisan buku ajar Konsep Pembiayaan Pendidikan Islam ini ditulis dalam 4 BAB yang berisi:

Bab 1 Konsep Dasar Pembiayaan Pendidikan

Dalam bab 1 ini dijelaskan tentang pengertian dan konsep dasar biaya pendidikan Islam serta penentu dan evaluasi biaya pendidikan.

Bab 2 Pendekatan Pembiayaan Pendidikan

Dalam bab 2 ini dijelaskan landasan hukum pembiayaan pendidikan, jenis dan cara mengukur biaya pendidikan, konsep efisiensi, penganggaran pendidikan Islam.

Bab 3 Prosedur Perencanaan dan Pengelolaan Anggaran Pendidikan

Dalam bab 3 ini dijelaskan pengertian perencanaan dan pengelolaan anggaran pendidikan, perencanaan dan pengelolaan anggaran lembaga pendidikan.

Bab 4 Pengelolaan Dan Pengalokasian Anggaran Pendidikan

Dalam bab 4 ini dijelaskan tentang pengelolaan dan pengalokasian anggaran dan keuangan Pendidikan, pengalokasian dana pendidikan serta tujuannya.

Bab 5 Tanggungjawab Pembiayaan Pendidikan

Dalam bab 5 ini dijelaskan tentang jaminan konstitusi pendanaan Pendidikan, tanggungjawab dalam pendanaan Pendidikan, sumber pendanaan Pendidikan 
Bab 6 Pembiayaan Pendidikan di Era Otonomi Daerah

Dalam bab 6 ini dijelaskan tentang pengertian dan tujuan otonomi daerah, dan sejarah, konsep baru pola pembiayaan pendidikan di era otonomi daerah.

Dengan selesainya penulisan buku ajar ini penulis mengucapkan terima kasih kepada semua pihak yang telah memberikan bahan-bahan tulisan baik langsung maupun tidak langsung. Penulis juga mengucapkan terima kasih khususnya kepada:

1. Dr. Hidayatullah, M.Si pemangku pimpinan tertinggi yaitu Rektor Universitas Muhammadiyah Sidoarjo yang telah memberikan dan memfasilitasi dalam penulisan buku ajar ini.

2. LP3iK Universitas Muhammadiyah Sidoarjo yang telah memfasilitasi dan mengkoordinasi dalam penulisan buku ajar ini.

3. Dr. Istikomah, M.Ag. sebagai Dekan Fakultas Agama Islam, Universitas Universitas Muhammadiyah Sidoarjo yang telah memberikan dukungan untuk mengikuti penulisan buku ajar ini.

4. Dr. Budi Haryanto, M.Pd. sebagai Kepala Program Studi Magister Manajemen Pendidikan Islam, Universitas Universitas Muhammadiyah Sidoarjo yang telah memberikan dukungan untuk mengikuti penulisan buku ajar ini.

5. Para narasumber, dosen serta teman-teman mahasiswa program studi Magister Manajemen Pendidikan Islam, Universitas Universitas Muhammadiyah Sidoarjo yang telah banyak membantu atas penyusunan penulisan buku ajar ini.

Akhir kata, kritik dan saran sangat diharapkan untuk penyempurnaan buku ajar ini. Harapan kami semoga buku ajar ini dapat digunakan sebagai tambahan informasi dan bermanfaat bagi aktivitas pembelajaran mata kuliah Konsep Pembiayaan Pendidikan Islam di Program Studi Magister Manajemen Pendidikan Islam, Fakultas Agama Islam, Universitas Universitas Muhammadiyah Sidoarjo.

Penulis 


\section{DAFTAR ISI}

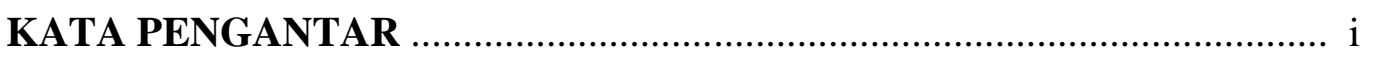

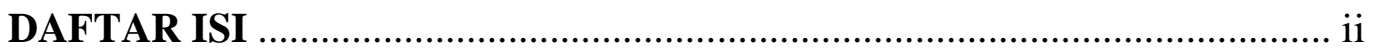

\section{BAB I KONSEP DASAR PEMBIAYAAN PENDIDIKAN}

A. Pengertian Biaya Pendidikan ................................................................ 1

B. Konsep Dasar Pembiayaan Pendidikan Islam .............................................. 2

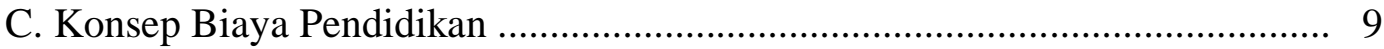

D. Penentu Biaya Pendidikan ......................................................................... 10

E. Evaluasi Pembiayaan Pendidikan ................................................................ 12

F. Standart Pembiayaan Pendidikan .............................................................. 13

\section{BAB II PENDEKATAN PEMBIAYAAN PENDIDIKAN}

A. Landasan Hukum Pembiayaan Pendidikan ............................................... 14

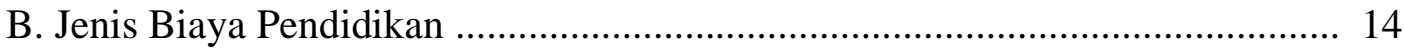

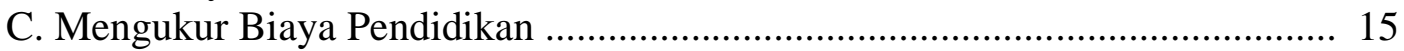

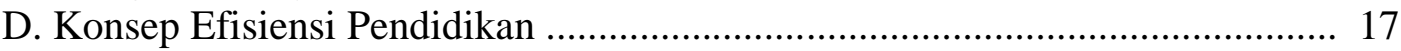

E. Penganggaran Biaya Pendidikan ............................................................ 18

\section{BAB III PROSEDUR PERENCANAAN DAN PENGELOLAAN ANGGARAN PENDIDIKAN \\ A. Pengertian Perencanaan Anggaran di Dalam Suatu Lembaga Pendidikan ...... 20 \\ B. Perencanaan Anggaran Lembaga Pendidikan ............................................... 21

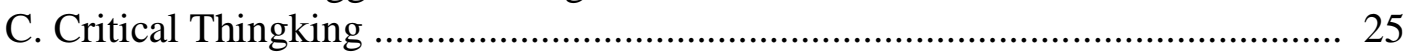 \\ D. Penegertian Pengelolaan Anggaran Lembaga Pendidikan .............................. 25}

\section{BAB IV PENGELOLAAN DAN PENGALOKASIAN ANGGARAN PENDIDIKAN}
A. Pengelolaan Keuangan Pendidikan .............................................................. 28
B. Pengelolaan Dana Pendidikan ................................................................... 29
C. Tujuan Pengalokasian Dan Pengelolaan Dana Pendidikan .............................. 31
D. Pengelolaan Anggaran Pendidikan Islam Pada Masa Klasik ........................... 31

\section{BAB V TANGGUNG JAWAB PEMBIAYAAN PENDIDIKAN}

A. Jaminan Konstutusi Pendanaan Pendidikan ....................................................... 34

B. Tanggung Jawab Dalam Pendanaan Pendidikan .......................................... 37

C. Sumber Pendanaan Pendidikan ....................................................................... 39

D. Sumber Pendanaan Pendidikan Islam Pada Masa Klasik ................................. 41

BAB VI PEMBIAYAAN PENDIDIKAN DI ERA OTONOMI DAERAH

A. Pengertian Dan Tujuan Otonomi Daerah ............................................................. 44

B. Sejarah Otonomi Daerah Di Indonesia ........................................................... 45

C. Konsep Baru Pola Pembiayaan Pendidikan Di Era Otonomi ............................ 47

D. Problematikan Pembiayaan Pendidikan Di Era Otonomi ................................. 51

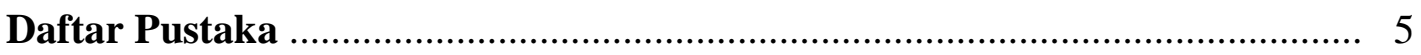




\section{BAB I \\ KONSEP DASAR PEMBIAYAAN PENDIDIKAN}

\section{A. Pengertian Biaya Pendidikan}

Pembiayaan pendidikan adalah salah satu sumber keuangan yang dapat menunjang efektivitas dan efisiensi pengelolaan pendidikan. Pembiayaan pendidikan merupakan salah satu sumber yang sangat berpotensi dalam menentukan sukses dan kelancaran progam pendidikan serta merupakan bagian yang tak terpisahkan dalam manajemen pengelolaan pendidikan. ${ }^{1}$

Menurut Dedi Supriadi dalam bukunya mendefinisikan biaya sebagai semua jenis pengeluaran yang berkenaan dengan penyelenggaraan pendidikan baik dalam bentuk uang, barang, dan tenaga (yang dapat dihargakan dengan uang). Pembiayaan merupakan upaya pengelolaan secara ekonomis yang dibuat guns memperoleh barang atau jasa.

Secara bahasa, biaya (cost) dapat diartikan sebagai pengeluaran, dalam istilah ekonomi biaya pengeluaran dapat berupa uang atau bentuk moneter lainnya. ${ }^{2}$ Menurut Hasbullah Pembiayaan sekolah adalah kegiatan mendapatkan biaya serta mengelola anggaran pendapatan dan belanja pendidikan. ${ }^{3}$

Pembiayaan pendidikan tidak lepas dari persoalan "ekonomi pendidikan". Bahkan, secara tegas Mark Blaugh mengemukakan bahwa "the economics of education is a branch of economics". Jadi, dapat dikatakan menurut pandangan ini bahwa pada dasarnya pembiayaan pendidikan merupakan bagian atau cabang dari ilmu ekonomi. Sebab, pembiayaan pendidikan menurut Blaugh sebgai the costing and financing of school places, yaitu bagian dari permasalahan ekonomi pendidikan. Pada bagian lain Mark Blaugh mengemukakan, "the economic of education is only part of the story of any educational issue". Menurut pandangan ini mengkaji ilmu ekonomi pendidikan maupun pembiayaan pendidikan hanya merupakan salah satu isu penting dalam dunia pendidikan. ${ }^{4}$

Menurut Yahya yang dikutip oleh Mulyono pembiayaan adalah bagaimana dana atau sumber dana dapat didapatkan dan bagaimana penggunaan dana tersebut dalam pemanfaatannya untuk rencana biaya standar, memperbesar modal kerja, dan merencanakan kebutuhan masa yang akan datang akan uang. ${ }^{5}$

Sedangkan Nanang Fattah mendefinisikan biaya pendidikan sebagai sejumlah uang atau dana yang digunakan untuk pembelanjaan berbagai keperluan

\footnotetext{
${ }^{1}$ Mulyasa, Manajemen Berbasis Sekolah (Bandung : PT Remaja Rosdakarya, 2002) hlm. 47

${ }^{2}$ Dedi Supriadi, Satuan Biaya Pendidikan SD, SLTP, SMU (Jakarta: Depdiknas, 2001) hlm. 3

${ }^{3}$ Hasbullah, Otonomi Pendidikan, (Jakarta: PT Raja Grafindo Persada, 2010), hlm. 122

${ }^{4}$ Mulyono, Konsep Pembiayaan Pendidikan......., hlm. 76

5 Ibid, hlm. 78
} 
penyelenggaraan pendidikan yaitu gaji guru, peningkatan profesional peralatan, pengadaan alat-alat dan buku pelajaran, alat tulis, kegiatan ekstrakulikuler, kegiatan pengelolaan pendidikan, dan supervisi pendidikan. ${ }^{6}$

\section{B. Konsep Dasar Pembiayaan Pendidikan Islam}

Dalam konsep pembiayaan pendidikan sedikitnya ada tiga pernyataan yang terkait didalamnya. Seperti yang telah dikemukakan oleh Thomas John yaitu bagaimana uang diperoleh untuk pembiayaan lembaga pendidikan, dari mana sumbernya, dan untuk apa dibelanjakannya serta siapa yang membelanjakan. Hal itu merupakan administrasi atau manajemen bisnis lembaga pendidikan. ${ }^{7}$

Selanjutnya Thomas menjelaskan tiga hal penting, yaitu ilmu ekonomi yang terkait dengan alokasi dan pembiayaan yang terkait dengan distribusi. Namun yang ketiga terkait dengan manajemen yang didalamnya mencakup fungsi dari komponen perencanaan, implementasi, dan evaluasi. Dengan demikian, ada perbedaan penekanan antara ekonomi pendidikan dan pembiayaan pendidikan. ${ }^{8}$

Pembiayaan pendidikan adalah sebuah aktivitas yang berkenaan dengan perolehan dana atau biaya pendapatan yang diterima dan penggunaan dana tersebut dipergunakan untuk membiayai seluruh program pendidikan yang telah ditetapkan. Pendapatan atau sumber dana pendidikan yang diterima sekolah diperoleh dari Anggaran Pendapatan dan Belanja Negara, Anggaran Pendapatan dan Belanja Daerah, dan masyarakat atau orang tua.

Bowen secara lebih terperinci menjelaskan bahwa:

"Revenues are derived from several sources: federal, state, and local appropriations, tuitions, gifts and grant from private individuals and corporations, endowment and sales of goods and services. The revenue theory of educational cost is subjuct to an important qualification.

Adapun penggunaan dana tersebut, setiap sekolah seharusnya menetapkan rencana-rencana yang menjadi prioritas pembiayaan pendidikan secara komprehensif. Perencanaan yang komprehensif dari sebuah program pembiayaan sekolah melibatkan pembuatan keputusan yang kritis dalam wilayah-wilayah utama berikut ini: ${ }^{9}$

1. Program pendidikan yang harus dibiayai.

2. Sistem pajak yang digunakan untuk pembiayaan program tersebut.

3. Sistem alokasi dana negara untuk wilayah atau daerah persekolahan.

\footnotetext{
${ }^{6}$ Ibid, hlm. 78

7 Thomas Jones, Introduction to School Finance: Tecnique and Social Policy, (Cambridge, Massachusetts: Ballinger Publishing, 1985), hlm. 20

${ }^{8}$ Ibid, hlm. 20

${ }^{9}$ Edgar Morphet, The Economic and Financing of Education, (New Jersey: Pergamon Press, 1985), hlm. 24
} 
Selain dari itu, perencanaan program pendidikan juga melibatkan keputusan kebijakan yang fundamental berkaitan dengan hal-hal berikut ini:

1. Siapa yang seharusnya dididik? Sasaran populasi apa yang seharusnya dilayani?

2. Tujuan-tujuan pendidikan apa yang seharusnya dibuat untuk setiap sasaran populasi?

3. Jenis program pendidikan apa yang dibutuhkan untuk sasaran populasi yang berbeda ini?

Ketika keputusan yang sesuai telah dibuat berkaitan dengan hal-hal penting di atas, maka langkah selanjutnya yang harus dilakukan adalah sebagai berikut: ${ }^{10}$

1. Mengetahui atau memastikan jumlah siswa saat ini dalam sasaran populasi yang berbeda dalam sebuah negara bagian dan memperhitungkan untuk sedikitnya periode 5 sampai 6 tahun yang diperkirakan dalam setiap kategori.

2. Menentukan jumlah dan persentase siswa pada setiap sasaran populasi yang akan dilayani oleh sebuah program, dirancang untuk memenuhi kebutuhan dari kategori tersebut.

3. Menentukan perbedaan di antara distrik dalam persentase pada setiap sasaran populasi.

4. Menentukan perluasan pada seluruh tujuan pendidikan dan tujuan dari setiap sasaran populasi yang diperoleh.

Keputusan pada pembiayaan sekolah dibuat baik pada pemerintahan pusat, provinsi, dan daerah. Keputusan yang dibuat pada ketiga level tersebut sering dibuat pada basis keadaan yang layak atau bermanfaat. Biasanya keputusan pada tiga level itu tidak terintegrasikan dengan baik pada program pembiayaan pendidikan. Jika perencanaan pembiayaan pendidikan diintegrasikan, hal itu jelas memerlukan perencanaan secara kooperatif atau secara bekerja sama. ${ }^{11}$

Pemerintah pusat tidak seharusnya membuat keputusan pada program pembiayaan sekolah tanpa berkonsultsi dengan pemerintah daerah dan pemerintah daerah (provinsi) tidak seharusnya membuat keputusan pada program pembiayaan sekolah tanpa berkonsultasi dengan pemerintah daerah. ${ }^{12}$

Oleh karena itu, masyarakat yang terlibat pada sekolah, seperti para administrator, para guru, dan personal pendukung lainnya harus dibawa dan dilibatkan dalam proses perencanaan jika perencanaan yang efisien ingin dicapai. Anggota dewan pembuat undang-undang dan dewan pendidikan lokal akan membuat

\footnotetext{
${ }^{10}$ Ibid, hlm.25

11 Akdon, Dedy Achmad Kurniadi, Manajemen Pembiayaan Pendidikan, (Bandung: Remaja Rosdakarya, 2017), hlm. 25

12 Ibid, hlm. 25
} 
keputusan yang lebih baik pada program pembiayaan sekolah jika memperbolehkan setiap orang berpartisipasi dalam proses perencanaan program tersebut.

Dalam hal ini kontribusi dari semua pihak yang terlibat dalam pendidikan akan membuat sebuah perencanaan yang lebih efektif dan efisien. Pentingnya penelitian dan informasi yang cukup untuk perencanaan pembiayaan sekolah tidak dapat dihindari. Tidak ada kelompok yang dapat membuat keputusan yang bergantung pada perencanaan pembiayaan sekolah jika tidak dapat mengantisipasi konsekuensi-konsekuensi dari keputusan-keputusan tersebut. ${ }^{13}$

Oleh karena itu, para pembuat keputusan pada kebijakan pembiayaan seharusnya menggunakan jasa para peneliti yang berkompeten pada pembiayaan sekolah yang dapat membantu mereka dalam mengevaluasi konsekuensi dari kebijakan-kebijakan alternatif.

Ada beberapa kebijakan umum yang biasa dianjurkan oleh para ahli dalam pembiayaan pendidikan. Kebijakan tersebut antara lain sebagai berikut: ${ }^{14}$

1. Jika masukan biaya tambahan akan menambah lebih banyak keuntungan secara individu dan sosial sistem pendidikan dibandingkan dengan jumlah investasi, maka masukan pembiayaan harus di tingkatkan.

2. Jika keuntungan secara individual dan sosial dari sistem organisasi dapat menghasilkan dengan masukan biaya yang lebih kecil, maka masukan pembiayaan seharusnya dikurangi.

3. Jika unit administrasi sekolah itu sendiri atau khusus dalam sekolah, merupakan unit yang sangat kecil dapat mencapai keuntungan dalam scala ekonomi penting untuk memaksimalkan keuntungan pendidikan, maka sistem sekolah harus ditinjau sistem organisasinya secara tepat.

4. Jika stuktur organisasi tidak berfungsi secara efisien dan efektif untuk memaksimalkan keuntungan pendidikan setiap pemasukannya, maka struktur organisasi itu harus dimodifikasi.

5. Jika setiap kebijakan pendidikan, program, atau cara kerja tidak berfungsi, tidak efektif dan tidak efisien, maka kebijakan pendidikan itu harus diubah.

Pembiayaan merupakan hal penting dalam keberhasilan penyelenggaraan pendidikan dan pemerintah memiliki peranan besar di dalamnya. Peran pemerintah mencakup pada perlindungan pemerintah terhadap anak dibawah umur, pengaruh eksternal peran pendidikan agar demokrasi berjalan, pemerataan kesempatan mendapatkan pendidikan bagi semua warga negara, peningkatan mutu dan relevansi pendidikan, serta tuntutan "norma umum" dan pengaruh pendidikan. ${ }^{15}$

\footnotetext{
${ }^{13}$ Ibid, hlm. 25

${ }^{14}$ Ibid, hlm. 26

15 Ibid, hlm. 26
} 
Disinilah peran pemerintah daerah dan pusat dalam mencurahkan dananya untuk membiayai penyelenggaraan pendidikan. Pada kondisi tersebut, maka alternatif pembiayaan pendidikan akan lebih tepat apabila menggunakan funding full state atau pembiayaan secara penuh oleh pemerintah pusat.

Implikasi dari dicurahkannya dana dalam bidang pendidikan pada masa krisis akan cukup menimbulkan kerepotan dalam berbagai hal, terutama yang terkait dengan usaha dalam meyakinkan berbagai pihak dan kalangan akan pentingnya recovery pembangunan bangsa melalui pembenahan penyelenggaraan pendidikan termasuk dalam pembiayaannya. ${ }^{16}$

Berkenaan dengan tingkatannya pembiayaan pendidikan terjadi di beberapa tempat atau tingkatan, yang meliputi lembaga satuan pendidikan yaitu sekolah, pengguna jasa pendidikan yaitu orang tua atau siswa dan administrator pendidikan dari tingkat kecamatan, kabupaten atau kota, provinsi, sampai tingkat pusat. Selain itu, pada masing-masing tingkatan, biaya pendidikan mencakup beberapa atau banyak komponen biaya. Dengan demikian, analisis biaya pendidikan akan lebih bermanfaat jika menggunakan pendekatan, tingkatan dan komponen biaya pendidikan.

Hampir disemua negara, pendidikan disediakan baik oleh sektor swasta maupun pemerintah. Distribusi kesempatan mengenyam pendidikan terhadap berbagai kelompok populasi memiliki konsekuensi sosial yang mempengaruhi pertumbuhan ekonomi dan distribusi pendapatan. Sistem pembiayaan pendidikan lebih kompleks dan untuk menilainya terdapat tiga kategori utama yang berkenaan dengan sistem pembiayaan pendidikan. Ketiga kategori tersebut adalah sebagai berikut: ${ }^{17}$

1. Apakah pembiayaan jasa pendidikan ini cukup memuaskan para stakeholder pendidikan?

2. Apakah pendistribusian alokasi dari sumber daya pendidikan yang bersumber dari pemerintah sudah cukup efisien?

3. Apakah pendistribusian alokasi dari sumber daya pendidikan ini cukup adil?

Pengukuran puas atau tidaknya stakeholder pendidikan berdasarkan persentase anggaran pemerintah terhadap PDB sering kali dianggap tidak cukup memuaskan karena tidak menghitung sektor pendidikan swasta dan pendapatan pendidikan di tingkat lokal. Yang akhirnya akan diperoleh dengan cara menghitung jumlah proporsi kelompok usia yang mendaftar serta menghitung proporsi wanita dan laki-laki.

${ }^{16}$ Ibid, hlm. 26

${ }^{17}$ Ibid, hlm. 27 
Sedangkan untuk menilai efisiensi sebuah institusi pendidikan dalam menjalankan fungsinya terdapat dua kriteria yaitu dapat ditinjau dari Cost-benefit dan Cost-effectiveness. Beberapa pendekatan yang dapat dilakukan untuk mengatasi masalah keadilan dalam penbiayaan pendidikan, antara lain pemerintah pusat membayar hampir seluruh biaya untuk pendidikan menengah keatas secara langsung kepada institusi masing-masing.

Adapun sistem pembiayaan pendidikan yaitu dimana proses pendapatan dan sumber daya tersedia dan dapat digunakan untuk memformulasikan serta mengoperasionalkan sekolah. Sistem pembiayaan pendidikan dapat ditentukan melalui kondisi masing-masing negara, seperti kondisi geografis, tingkat pendidikan, kondisi politik pendidikan, hukum pendidikan, ekonomi pendidikan, program pembiayaan pemerintah dan administrasi sekolah dan lain sebagainya. ${ }^{18}$

Disamping itu, terdapat beberapa faktor yang perlun diperhatikan untuk mengetahui sesuai tidaknya sistem dengan kondisi negara. Untuk mengetahui apakah sistem tersebut memuaskan, dapat dilakukan dengan cara menghitung berbagai proporsi dari kelompok usia, jenis kelamin, tingkat buta huruf, dan mendistribusi alokasi sumber daya pendidikan secara efisien dan adil sebagai kewajiban pemerintah pusat untuk memberikan subsidi terhadap sektor pendidikan dibanding dengan sektor lainnya.

Setiap keputusan dalam masalah pembiayaan sekolah akan mempengaruhi bagaimana sumber daya diperoleh dan dialokasi. Oleh sebab itu, perlu dilihat siapa yang akan dididik dan seberapa banyak jasa pendidikan yang dibutuhkan. Demikian pula dengan sistem pemerintahan yang seperti apa yang sesuai dan mendukung sistem pembiayaan pendidikan. ${ }^{19}$

Pembiayaan sekolah merupakan upaya guna mendapatkan pendapatan anggaram dan sumber daya yang tersedia digunakan untuk memformulasikan sekolah diberbagai wilayah dan tingkat pendidikan yang meragam. Pembiayaan sekolah berkaitan dengan seluruh anggaran dalam politik pendidikan dan program pembiayaan pemerintah serta administrasi sekolah. ${ }^{20}$

Dalam pembiayaan pembiayaan sekolah tidak ada pendekatan tunggal dan yang paling baik untuk pembiayaan semua sekolah karena kondisi setiap sekolah berbeda. Setiap kebijakan dalam pembiayaan sekolah akan mempengaruhi bagaimana sumber daya diperoleh dan dialokasikan. Dengan mengkaji berbagai peraturan dan kebijakan yang berbeda-beda disektor pendidikan, kita bisa melihat konsekuensinya dalam bidang pendidikan, yaitu sebagai berikut:

1. Keputusan tentang siapa yang akan dididik dan seberapa banyak jasa pendidik dapat disediakan.

\footnotetext{
${ }^{18}$ Ibid, hlm. 27

${ }^{19}$ Ibid, hlm. 28

${ }^{20}$ Ibid, hlm. 28
} 
2. Keputusan tentang bagaimana mereka akan dididik.

3. Keputusan tentang siapa yang akan membayar biaya pendidikan.

4. Keputusan tentang sistem pemerintahan yang seperti apa yang paling sesuai untuk mendukung pembiayaan sekolah.

Dalam Islam, pembiayaan pendidikan untuk seluruh tingkatan sepenuhnya merupakan tanggung jawab negara. Seluruh pembiayaan pendidikan, baik menyangkut gaji para guru/dosen, maupun menyangkut infrastruktur serta sarana dan prasarana pendidikan, sepenuhnya menjadi kewajiban negara. Ringkasnya, dalam Islam, pendidikan disediakan secara gratis oleh negara. Mengapa demikian? Sebab negara berkewajiban menjamin tiga kebutuhan pokok masyarakat, yaitu pendidikan, kesehatan, dan keamanan. Berbeda dengan kebutuhan pokok individu, yaitu sandang, pangan, dan papan, di mana negara memberi jaminan tak langsung. Sementara itu, dalam hal pendidikan, kesehatan, dan keamanan, jaminan negara bersifat langsung. Maksudnya, tiga kebutuhan ini diperoleh secara cuma-cuma sebagai hak rakyat atas negara. Nabi SAW bersabda: "Imam adalah bagaikan penggembala dan dialah yang bertanggung jawab atas gembalaannya itu." Lebih dari itu, setelah perang Badar, sebagian tawanan yang tidak sanggup menebus pembebasannya, diharuskan mengajari baca tulis kepada sepuluh anak-anak Madinah sebagai ganti tebusannya. Ini menunjukkan perhatian pemimpin Islam pada masalah pendidikan umat Islam. ${ }^{21}$

Ijma' sahabat juga telah menunjukkan kewajiban negara menjamin pembiayaan pendidikan. Khalifah Umar dan Utsman memberikan gaji kepada para guru, muadzin, dan imam sholat jama'ah. Khalifah Umar memberikan gaji tersebut dari pendapatan negara (Baitul Mal) yang berasal dari jizyah, kharaj (pajak tanah), dan usyur (pungutan atas harta non muslim yang melintasi tapal batas negara). Sejarah Islam pun telah mencatat kebijakan para khalifah yang menyediakan pendidikan gratis bagi rakyatnya. Sejak abad IV H para khalifah membangun berbagai perguruan tinggi dan berusaha melengkapinya dengan berbagai sarana dan prasarananya seperti perpustakaan. Setiap perguruan tinggi itu dilengkapi dengan "Diwan" (auditorium), asrama mahasiswa, juga perumahan dosen dan ulama. Selain itu, perguruan tinggi tersebut juga dilengkapi taman rekreasi, kamar mandi, dapur, dan ruang makan. ${ }^{22}$

${ }^{21}$ Ahmad Munir, Manajemen Pembiayaan Pendidikan Dalam Perspektif Islam, AT-Ta'dib : 02 (2013), 231.

22 Ibid, HIm. 232. 
Di antara perguruan tinggi terpenting adalah Madrasah Nizhamiyah dan Madrasah Al-Mustanshiriyah di Baghdad, Madrasah Al-Nuriyah di Damaskus, serta Madrasah An-Nashiriyah di Kairo. Madrasah Mustanshiriyah didirikan oleh Khalifah Al-Mustanshir pada abad VI H dengan fasilitas yang lengkap. Selain memiliki auditorium dan perpustakaan, lembaga ini juga dilengkapi pemandian dan rumah sakit yang dokternya selalu siap di tempat. Pada era Khilafah Utsmaniyah, Sultan (Khalifah) Muhammad AlFatih (w. 1481 M) juga menyediakan pendidikan secara gratis. Di Konstantinopel (Istanbul) Sultan membangun delapan sekolah. Di sekolah-sekolah ini dibangun asrama siswa, lengkap dengan ruang tidur dan ruang makan. Sultan memberikan beasiswa bulanan untuk para siswa. Dibangun pula sebuah perpustakaan khusus yang dikelola oleh pustakawan yang cakap dan berilmu.

Namun perlu dicatat, meski pembiayaan pendidikan adalah tanggung jawab negara, Islam tidak melarang inisiatif rakyatnya, khususnya mereka yang kaya, untuk berperan serta dalam pendidikan. Melalui wakaf yang disyariatkan, sejarah mencatat banyak orang kaya yang membangun sekolah dan universitas. Hampir di setiap kota besar, seperti Damaskus, Baghdad, Kairo, Asfahan, dan lainlain, terdapat lembaga pendidikan dan perpustakaan yang berasal dari wakaf. Di antara wakaf ini ada yang bersifat khusus, yakni untuk kegiatan tertentu atau orang tertentu. Seperti wakaf untuk ilmuwan hadits, wakaf khusus untuk dokter, wakaf khusus untuk riset obat-obatan, wakaf khusus guru anak-anak, wakaf khusus untuk pendalaman fikih dan ilmu-ilmu Al-Qur'an. Bahkan sejarah mencatat ada wakaf khusus untuk Syaikh Al-Azhar atau fasilitas kendaraannya. Selain itu, wakaf juga diberikan dalam bentuk asrama pelajar dan mahasiswa, alat-alat tulis, buku pegangan, termasuk beasiswa dan biaya pendidikan.Walhasil, dalam Islam, rakyat harus memperoleh pendidikan formal yang gratis dari negara. Sedangkan melalui inisiatif wakaf dari anggota masyarakat yang kaya, rakyat akan memperoleh pendidikan non formal yang juga gratis atau paling tidak murah bagi rakyat. ${ }^{23}$

Bertolak dari pemahaman di atas, pada dasarnya konsep pembiayaan pendidikan dalam Islam, secara historis telah dilaksanakan dengan baik pada masa Rasul, kemudian dikembangkan pada waktu masa khalifah. Sistem pendidikan formal yang diselenggarakan negara khilafah memperoleh sumber pembiayaan sepenuhnya

${ }^{23}$ Ibid, HIm. 232-233. 
dari negara (Baitul Mal). Dalam sejarah, pada masa Khalifah Umar bin Khaththab, sumber pembiayaan untuk kemaslahatan umum (termasuk pendidikan), berasal dari jizyah, kharaj (pajak tanah), dan usyur (pungutan atas harta non muslim yang melintasi tapal batas negara). Setidaknya terdapat dua sumber pendapatan Baitul Mal yang dapat digunakan untuk membiayai pendidikan, yaitu:

1. Pos fai' dan kharaj yang merupakan kepemilikan negara, seperti ghanimah, khumus (seperlima harta rampasan perang), jizyah, dan dharibah (pajak);

2. Pos kepemilikan umum, seperti tambang minyak dan gas, hutan, laut, dan hima (milik umum yang penggunaannya telah dikhususkan). Sedangkan pendapatan dari pos zakat, tidak dapat digunakan untuk pembiayaan pendidikan, karena zakat mempunyai peruntukannya sendiri, yaitu delapan golongan mustahik zakat.

Jika dua sumber pendapatan itu ternyata tidak mencukupi, dan dikhawatirkan akan timbul efek negatif (dharar) jika terjadi penundaan pembiayaannya, maka negara wajib mencukupinya dengan segera dengan cara berhutang (qardh). Hutang ini kemudian dilunasi oleh negara dengan dana dari dharibah (pajak) yang dipungut dari kaum muslimin. Biaya pendidikan dari Baitul Mal itu secara garis besar dibelanjakan untuk 2 (dua) kepentingan. Pertama, untuk membayar gaji segala pihak yang terkait dengan pelayanan pendidikan, seperti guru, dosen, karyawan, dan lain-lain. Kedua, untuk membiayai segala macam sarana dan prasana pendidikan, seperti bangunan sekolah, asrama, perpustakaan, buku-buku pegangan, dan sebagainya. ${ }^{24}$

\section{Konsep Biaya Pendidikan}

Konsep biaya dalam bahasa Inggris biasa menggunakan istilah cost, financisal, expenditure. Biaya pendidikan dapat dibedakan menjadi dua unsur yaitu meliputi biaya langsung dan biaya tidak langsung. Biaya langsung terdiri dari biaya-biaya yang dikeluarkan untuk keperluan pelaksanaan pengajaran dan kegiatan belajar siswa. Sedangkan biaya langsung dapat bersumber dari anggaran tetap sekolah seperti SPP, uang gedung, sumbangan orang tua atau yang dikeluarkan sendiri oleh siswa untuk membeli perlengkapan demi kelangsungan proses pendidikan, seperti biaya buku, peralatan kelas dan uang saku.

Sedangkan biaya tidak langsung meliputi hilangnya pendapatan peserta didik karena sedang mengikuti pendidikan. Bisa juga dalam bentuk biaya kesempatan yang hilang yang dikorbankan oleh siswa selama dalam proses pembelajaran.

${ }^{24}$ Ibid, HIm. 233-234. 
Menurut kutipan Dedi Darmawan, Cohn dan Geske mengelompokkan biaya pendidikan sebagai berikut:

1. Biaya langsung (direct cost), yaitu biaya yang dikeluarkan sekolah, siswa dan keluarga siswa.

2. Biaya tidak langsung (indirect cost), yaitu biaya diluar anggaran dari sekolah.

3. Jenis pendidikan.

4. Tingkat pendidikan dan jurusan.

5. Sifat pengeluaran yaitu biaya program pengajaran per jam yaitu meliputi gaji guru dan tenaga administrasi, biaya ruang, biaya sarana dan prasarana, biaya bahan dan alat pembelajaran.

Dalam perhitungan biaya dalam pendidikan akan ditentukan oleh unsur-unsur diatas yang didasarkan pada perhitungan biaya yang nyata dan sesuai dengan kegiatan menurut jenis dan volumenya. Konsep pembiayaan pendidikan mengacu pada dua hal penting yaitu biaya pendidikan secara keseluruhan dan biaya satuan per siswa.

Biaya pendidikan bukan hanya berbentuk uang atau rupiah, tetapi dalam bentuk biaya kesempatan. Biaya kesempatan yang hilang yaitu potensi pendapatan bagi seorang siswa selama ia mengikuti pelajaran atau menyelesaikan bidang studi. Biaya kesempatan yang hilang terfokus pada pendapatan yang hilang oleh siswa karena sekolah itu sendiri, pembebasan pajak yang secara umum dinikmati oleh lembaga nirlaba, biaya yang berkenaan dengan penyusutan dan bunga bank yaitu bangunan dan perlengkapan sekolah.

Biaya pendidikan adalah sebuah dasar dan landasan untuk memberikan gambaran atau karakteristik keuangan sekolah. Biaya satuan tingkat sekolah merupakan biaya pendidikan tingkat sekolah yang bersumber dari pemerintah, orang tua maupun masyarakat yang dikeluarkan guna penyelenggaraan pendidikan dalam satu tahun ajaran. $^{25}$

\section{Penentu Biaya Pendidikan}

Untuk memberikan petunjuk kepada pembuat kebijakan, para perencana pendidikan harus mampu membuat ramalan yang akurat mengenai biaya pendidikan pada masa yang akan datang sebagaimana sumber yang diperlukan dan sumber yang tersedia. Sistem analisis dapat membantu para perencana mendistribusikan dan menguji berbagai penentu dan menjelaskan masa yang akan datang sebagaimana sumber yang diperlukan dan sumber yang tersedia.

Penentu biaya internal berhubungan dengan teknologi yang digunakan dalam pendidikan dan kebijakan yang diadopsi, khususnya pembayaran, pembangunan dan penggunaan guru. Sedangkan pendidikan dengan menggunakan tenaga kerja intensif

\footnotetext{
${ }^{25}$ Nanang Fattah, Ekonomi dan Pembiayaan Pendidikan, (Bandung: Remaja Rosdakarya, 2000), hlm. 25
} 
dan teknologi yang tinggi meliputi input sumber daya manusia dan input fisik adalah 60 $\%$ total biaya pendidikan untuk biaya staf. ${ }^{26}$

Adapun penyebab utama yang meliputi peningkatan biaya pendidikan adalah sebagai berikut:

a. Inflasi yaitu pengaruh inflasi pada pendidikan disebabkan oleh naiknya pengeluaran pendidikan. Hal ini merupakan bagian yang dicerminkan inflasi harga dan gaji. Inflasi menyebabkan anggaran dan gaji hampir tertinggal oleh kenaikan umum harga dan gaji, dengan merampas pengeluaran nyata pendidikan dan mengurangi kemampuan menarik dan menahan guru-guru dan pengurus yang baik. Naiknya pengeluaran untuk pendidikan mengangkat keseluruhan anggaran pemerintah.

b. Pemerintah pendidikan yaitu pengaruh naiknya permintaan dalam biaya pendidikan merupakan penyebab terbesar naiknya pengeluaran keseluruhan pendidikan. Empat faktor penyebab meningkatnya hal ini adalah

1) Kenaikan terbaik pada populasi pemuda.

2) Revolusi naiknya harapan pada pihak yang kehilangan kesempatan pendidikan dan menganggap pendidikan sebagai kunci kemajuan individu.

3) Meluasnya adopsi kebijakan umum yang bertujuan untuk mendemokratisasikan kesempatan pendidikan pada hampir semua negara berkembang pada awal 1960.

4) Pengembangan, penataan, penggolongan kebutuhan tenaga manusia yang pesat karena kemajuan teknologi dalam ekonomi, penekanan baru kebijakan umum dalam hal perkembangan ekonomi.

Sumber pendanaan pendidikan sebagaimana dinyatakan pada UU RI No. 20 tahun 2003 tentang Sisdiknas Pasal 46 ayat (1) yaitu pendanaan pendidikan menjadi tanggung jawab bersama antara Pemerintah, Pemerintah Daerah dan masyarakat. ${ }^{27}$ Pembiayaan pendidikan terbagi menjadi 2 yaitu :

\section{a) Pembiayaan Pendidikan di Sekolah Swasta}

Pembiayaan pendidikan dari Swasta adalah biaya pendidikan dari swasta, atau biaya yang disumbangkan oleh masyarakat yang berperan dalam lembaga tersebut bisa juga oleh individu, perusahaan, lembaga nonpemerintah, dan lain sebagainya kepada sekolah. Sedangkan pembiayaan pendidikan dari Masyarakat bersumber pada biaya sumbangan yang diberikan dari orang tua siswa, sumbangan perusahaan swasta, dan lainnya.

\footnotetext{
${ }^{26}$ Akdon, Dedy Achmad Kurniadi, Manajemen Pembiayaan Pendidikan......, hlm. 11

${ }^{27}$ Undang-Undang RI No.20 Tahun 2003 tentang Sistem Pendidikan Nasional (SISDIKNAS), (Bandung: Citra Umbara, 2006), hlm 99.
} 
Sedangkan yang dimaksud dengan sumbangan orang tua siswa adalah dana yang disumbangkan langsung ke sekolah oleh orang tua siswa atau dikenal dengan dana komite sekolah. Dana tersebut terdiri atas Sumbangan Pengembangan Institusi dan Dana Operasional Pendidikan.

\section{b) Pembiayaan Pendidikan di Sekolah Negeri}

Pembiayaan Pendidikan dari Pemerintah Pusat : Menurut Undang-Undang No.22 tahun 1999 tentang otonomi daerah, maka pengelolaan pendidikan menengah diserahkan kepada pemkab/pemkot. Aliran dana dari pusat ke daerah dilakukan melalui mekanisme dana perimbangan, khususnya melalui Dana Alokasi Umum (DAU).

Menurut UU No.25 tahun 1999 tentang perimbangan keuangan antara pusat dan daerah, selain DAU, dana perimbangan yang diterima pemerintah daerah adalah dana bagi hasil dan Dana Alokasi Khusus (DAK). Sumber penerimaan daerah lainnya adalah Pendapatan Asli Daerah (PAD), dan pinjaman daerah.

Semua penerimaan dan pengeluaran dalam rangka desentralisasi dicatat dan dikelola dalam APBD. Pembiayaan Pendidikan dari Pemerintah Kabupaten/Kota: Biaya pendidikan dari pemerintah kabupaten/kota yang diterima digunakan untuk belanja administrasi umum yang terdiri dari: belanja pegawai, belanja barang dan jasa pemeliharaan. Biaya dari pemkab/pemkot lainnya adalah dana beasiswa untuk siswa dan dana subsidi untuk penyelenggaraan ujian sekolah dan ujian nasional. ${ }^{28}$

\section{E. Evaluasi Pembiayaan Pendidikan}

Evaluasi pendidikan juga diartikan dengan proses untuk memberikan kualitas yaitu nilai dari kegiatan pendidikan yang telah dilaksanakan, yang mana proses tersebut berlangsung secara sistematis, berkelanjutan, terencana, dan dilaksanakan sesuai dengan prosedur. $^{29}$

Proses melakukan evaluasi mungkin saja berbeda sesuai persepsi teori yang dianut, ada bermacam-macam cara. Dalam evaluasi pembiayaan pendidikan harus memasukkan ketentuan maupun tindakan yang sejalan dengan fungsi evaluasi, yaitu memfokuskan evaluasi, mendesain evaluasi, mengumpulkan informasi, menganalisis informasi, melaporkan hasil evaluasi serta mengelola evaluasi dan mengevaluasi evaluasi.

Evaluasi pembiayaan pendidikan merupakan alat untuk mengukur dari melihat hasil rencana yang dicanangkan pada planning. Memberikan imbalan kepada staff sesuai kinerja yang ditunjukkan, dan merancang serta merencanakan kembali sambil memperbaiki hal-hal yang belum sempurna. ${ }^{30}$

Evaluasi dalam administrasi pembiayaan merupakan kegiatan mengukur tingkat efektivitas kerja individu dan tingkat efisiensi penggunaan metode atau alat bantu tertentu

\footnotetext{
${ }^{28}$ Muhammad Anis, Manajemen Pembiayaan Pendidikan di SDIT Assalamah Ungaran, Skripsi hlm 17-20

${ }^{29}$ Zaenal Arifin, Evaluasi Pembelajaran, (Bandung: Rosda, 2010), cet. 2, hlm. 5-6.

${ }^{30}$ Ashar Arsyad, Pokok Manajemen, (Yogyakarta: Pustaka Pelajar, 2002), hlm. 20.
} 
dalam usaha guna mencapai tujuan pembiayaan. ${ }^{31}$ Mengamati tingkat efektivitas maksudnya menilai tindakan tindakan atau kegiatan-kegiatan yang telah dilakukan, apakah telah menghasilkan sesuatu seperti direncanakan atau sekurangkurangnya, apakah kegiatan itu telah berjalan di atas rel yang sebenarnya dan tidak menyimpang dari perencanaan atau tujuan yang telah ditetapkan.

Mengamati tingkat efisiensi yaitu dengan menilai tindakan-tindakan atau kegiatan-kegiatan yang telah dilakukan itu apakah merupakan cara yang terbaik atau paling tidak untuk mencapai hasil yang sebesar besarnya dengan resiko yang sekecilkecilnya. Evaluasi pembiayaan pendidikan berguna sebagai bentuk pertimbangan menurut seperangkat kriteria yang disepakati dan dapat dipertanggungkan. Tujuannya yaitu untuk mengukur, membandingkan, menilai alokasi biaya dan tingkat penggunaanya. ${ }^{32}$

\section{F. Standar Pembiayaan Pendidikan}

Standar pembiayaan berdasarkan peraturan pemerintah Nomor 19 Tahun 2005 pasal 62 terdiri atas :

a. Biaya investasi satuan pendidikan yang meliputi biaya penyediaan sarana dan prasarana, pengembangan sumberdaya manusia, dan modal kerja tetap.

b. Biaya personal adalah biaya yang mencakup biaya pendidikan yang harus dikeluarkan oleh peserta didik untuk bisa mengikuti proses pembelajaran secara teratur dan berkelanjutan.

c. Biaya operasi satuan pendidikan yaitu berupa gaji pendidik dan tenaga kependidikan dan segala tunjangan yang melekat pada gaji, bahan bangunan atau peralatan pendidikan dan biaya operasional pendidikan tidak langsung yang berupa daya, air, jasa telekomunikasi, pemeliharaan sarana dan prasarana, uang lembur, transportasi, konsumsi, pajak, asuransi, dan sebagainya.

Dalam upaya menjaga mutu pendidikan yang baik dibutuhkan standar pembiayaan minimal yang dapat dirumuskan dengan memperhitungkan seluruh biaya personil yaitu gaji guru dan staff, tunjangan dan faktor yang mencakup pada gaji pokok, anggaran peralatan alat tulis sekolah, biaya rapat, biaya penilaian, biaya pemeliharaan, biaya kesejahteraan, biaya pembinaan serta daya dan jasa dalam proses belajar mengajar.

Standar pembiayaan pendidikan mrupakan biaya minimum yang diperlukan sebuah lembaga pendidikan guna dapat melaksanakan kegiatan pendidikan selama satu tahun. Anggaran atau biaya disini meliputi biaya investasi, biaya operasi, dan biaya personal. Biaya yang dimaksud adalah biaya minimum yang harus dikeluarkan untuk setiap satuan lembaga pendidikan dan juga setiap jalur pendidikanya.

\footnotetext{
${ }^{31}$ Hadori Nawawi, Administrasi Pendidikan, Jakarta: Gunung Agung, 1996. Hlm 43

${ }^{32}$ Nanang Fattah, Ekonomi dan Pembiayaan Pendidikan.......,hlm. 65
} 


\section{BAB II \\ PENDEKATAN PEMBIAYAAN PENDIDIKAN}

\section{A. Landasan Hukum Pembiayaan Pendidikan}

UUD Negara Republik Indonesia 1945 menyatakan bahwa setiap warga negara berhak untuk mendapat pendidikan, setiap warga negara wajib mengikuti pendidikan dasar dan pemerintah wajib membiayainya. Partisipasi masyarakat dalam pendidikan berbasis masyarakat adalah dengan berperan serta dalam pengembangan, pelaksanaan kurikulum, evaluasi pendidikan, manajemen dan pendanaannya yang sesuai dengan standar nasional pendidikan. Dana penyelenggaraan pendidikan berbasis masyarakat dapat bersumber dari penyelenggara, masyarakat, Pemerintah, Pemerintah Daerah dan atau sumber lain yang tidak bertentangan dengan peraturan perundang-undangan yang berlaku.

UU No. 20 Tahun 2003 tentang Sistem Pendidikan Nasional Pasal 11 Ayat 2 Pemerintah dan Pemerintah Daerah wajib menjamin tersedianya anggaran guna terselenggaranya pendidikan bagi setiap warga negara yang berusia tujuh sampai lima belas tahun. UU No. 20 Tahun 2003 tentang Sistem Pendidikan Nasional Pasal 12, Ayat 1 Setiap peserta didik pada setiap satuan pendidikan berhak mendapatkan beasiswa bagi yang berprestasi yang orangtuanya tidak mampu membiayai pendidikannya dan mendapatkan biaya pendidikan bagi mereka yang orangtuanya tidak mampu membiayai pendidikannya. Setiap peserta didik berkewajiban ikut menanggung biaya penyelenggaraan pendidikan, kecuali bagi peserta didik yang dibebaskan dari kewajiban tersebut sesuai dengan peraturan perundang-undangan yang berlaku. ${ }^{33}$

\section{B. Jenis Biaya Pendidikan}

Dalam Peraturan Pemerintah Nomer 48 tahun 2008 tentang Penganggaran Pendidikan tertuang pernyataan bahwa pendanaan pendidikan menjadi tanggung jawab bersama antara pemerintah, pemerintah daerah, dan masyarakat. Biaya pendidikan dikelompokkan menjadi:

1. Biaya satuan pendidikan

Merupakan biaya penyelenggaraan pendidikan pada tingkat satuan pendidikan yang didalamnya mencakup biaya operasional, biaya investasi, bantuan biaya pendidikan dan beasiswa.

2. Biaya penyelenggaraan pendidikan

Merupakan biaya penyelenggaraan dan atau pengelolaan pendidikan oleh pemerintah pusat, pemerintah provinsi, pemerintah kota atau pemerintah kabupaten, dan penyelenggara satuan pendidikan yang didirikan masyarakat.

\footnotetext{
${ }^{33}$ UU No. 20 Tahun 2003 Tentang Sistem Pendidikan Nasional
} 
3. Biaya pribadi peserta didik

Merupakan biaya operasional yang didalamnya mencakup biaya pendidikan yang harus dikeluarkan oleh peserta didik untuk dapat mengikuti proses pembelajaran secara teratur dan berkelanjutan. ${ }^{34}$

Setiap kebijakan pembiayaan pendidikan akan berpengaruh terhadap sumber dana yang diperoleh dan sumber dana yang dialokasikan. Sumber dana yang diperoleh berhubungan dengan pendapatan, sedangkan sumber dana yang dialokasikan berhubungan dengan kegiatan belanja. Dengan menerapkan kebijakan yang berbeda, akan berpengaruh terhadap keputusan yang berdampak pada pembiayaan pendidikan. Pembiayaan pendidikan yang baik adalah model pembiayaan yang mengacu pada peraturan perundangan-undangan yang berlaku agar seluruh proses pengelolaan pembiayaan pendidikan tidak melanggar hukum.

Pembiayaan pendidikan terdiri atas biaya investasi, biaya operasional, dan biaya personal.

a. Biaya investasi satuan pendidikan meliputi biaya pengadaan sarana dan prasarana, pengembangan sumber daya manusia, dan modal kerja tetap.

b. Biaya personal meliputi biaya pendidikan yang harus dikeluarkan oleh peserta didik untuk bisa mengikuti proses pembelajaran secara teratur dan berkelanjutan.

c. Biaya operasional satuan pendidikan sebagaimana dimaksud di atas meliputi:

1) Gaji pendidik dan tenaga kependidikan serta segala tunjangan yang melekat pada gaji.

2) Bahan atau peralatan pendidikan habis pakai

3) Biaya operasi pendidikan tak langsung berupa daya, air, jasa telekomunikasi, pemeliharaan sarana dan prasarana, uang lembur, transportasi, konsumsi, pajak, asuransi, dan lain sebagainya

\section{Mengukur Biaya Pendidikan}

Biaya pendidikan secara keseluruhan (total cost) dan biaya satuan (unit cost) merupakan dua hal penting yang perlu dikaji atau dianalisis dalam konsep dasar pembiayaan pendidikan. Biaya satuan ditingkat sekolah merupakan aggregate biaya pendidikan tingkat sekolah baik yang bersumber dari pemerintah, orang tua, dan masyarakat yang dikerluarkan untuk menyelenggarakan pendidikan dalam satu tahun pelajaran. Sedangkan biaya satuan per siswa merupakan ukuran yang menggambarkan besaran dana yang dialokasikan oleh lembaga secara efektif untuk kepentingan siswa dalam menempuh pendidikannya. Oleh karena biaya satuan ini diperoleh dengan memperhitungkan jumlah siswa pada masingmasing sekolah, maka ukuran biaya satuan dianggap standar dan dapat dibandingkan antara lembaga sekolah yang satu dengan lembaga lainnya.

\footnotetext{
${ }^{34}$ Peraturan Pemerintah Nomer 48 tahun 2008 tentang Penganggaran Pendidikan
} 
Analisis mengenai biaya satuan dalam kaitannya dengan faktor-faktor lain yang mempengaruhinya dapat dilakukan dengan menggunakan sekolah sebagai unit analisis. Melalui analisa biaya satuan kita bisa mengetahui efisiensi penggunaan sumber-sumber di sekolah, keuntungan dari investasi pendidikan, pemerataan pengeluaran masyarakat dan pemerintah untuk pendidikan. Selain itu, kita juga bisa menggunakan analisis biaya satuan sebagai alternatif kebijakan dalam upaya perbaikan atau peningkatan sistem pendidikan. Pendekatan makro dan mikro merupakan dua pendekatan yang bisa digunakan untuk mengukur besaran biaya pendidikan.

\section{Pendekatan Makro}

Disetiap negara, faktor utama yang menentukan besaran perhitungan biaya satuan dalam sistem pendidikan adalah kebijakan dalam pengalokasian anggaran pendidikan. Dikarenakan adanya perbedaan cara dalam menyelenggarakan pendidikan, maka besaran satuan biaya pendidikan disetiap negarapun bervariasi. Untuk membandingkan biaya pendidikan pada tiap jenjang di setiap negara, metode yang digunakan adalah dengan membandingkan biaya operasional pendidikan dan sumber keuangannya, yang bisa dilihat dari persentase GNP (gross national product) dari tiap negara.

\section{Pendekatan Mikro}

Pendekatan ini menganalisis biaya pendidikan berdasarkan pengeluaran total dan jumlah biaya satuan menurut jenis dan tingkat pendidikan. Satuan biaya ini merupakan fungsi dari besarnya pengeluaran sekolah serta banyaknya siswa. Dengan demikian, satuan biaya ini dapat diketahui dengan jalan membagi seluruh jumlah pengeluaran sekolah setiap tahun dengan jumlah murid sekolah pada tahun yang bersangkutan.

Untuk menghitung satuan biaya pendidikan digunakan formula perhitungan sebagai berikut:

$$
\operatorname{Sb}(s, t)=\mathbf{f}[K(s, t): M(s, t)]
$$

Keterangan:

$\mathrm{Sb}$ : Satuan biaya murid per tahun

$\mathrm{K}$ : Jumlah seluruh pengeluaran.

$\mathrm{M}$ : Jumlah murid

s : Sekolah tertentu

$\mathrm{t}$ : tahun tertentu

Tujuan dari analisis biaya adalah untuk memberikan informasi dan memberikan kemudahan kepada para pengambil keputusan untuk menentukan kebijakan sekolah lebih lanjut. Selain itu juga, analisais biaya digunakan untuk efektivitas maupun efisiensi pengolahan anggaran serta peningkatan mutu pendidikan.

Secara khusus, analisis manfaat biaya pendidikan dijadikan acuan bagi pemerintah untuk menetapkan anggaran pendidikan dalam RAPBN, disamping juga sebagai dasar untuk 
meningkatkan kualitas SDM dengan meningkatkan mutu pendidikan nasional. Bagi masyarakat, analisis manfaat biaya pendidikan ini digunakan sebagai dasar untuk melakukan "investasi" di dunia pendidikan. Hal ini menjadi penting untuk dikaji dan dipelajari, karena pada sebagian masyarakat ada pemahaman konsep bahwa pendidikan hanya menghabishabiskan uang tanpa ada jaminan peningkatan hidup yang jelas dimasa mendatang.

\section{Konsep Efisiensi Pendidikan}

Istilah efisiensi digambarkan sebagai hubungan antara pemasukan dan pengeluaran. Sebuah sistem yang efisien ditunjukkan oleh keluaran yang lebih untuk sumber masukan (resources input). Efisiensi pendidikan bisa juga diartikan sebagai pemanfaatan sumbersumber pendidikan yang terbatas sehingga mencapai hasil yang maksimal. Untuk mengetahui tingkat efisiensi biaya pendidikan biasanya digunakan metode analisis keefektifan biaya (cost effectiveness method) dengan memperhitungkan besarnya kontribusi setiap masukan pendidikan terhadap efektivitas pencapaian tujuan pendidikan.

Upaya efisiensi pendidikan dapat dibagi menjadi dua kategori, yaitu:

1. Efisiensi Internal

Sebuah sistem pendidikan dinilai memiliki efisiensi internal apabila dapat menghasilkan output yang diharapkan dengan biaya minimum. Dalam konsep pelaksanaan efisiensi internal, kebijakan yang bisa dilakukan untuk menekan biaya pendidikan antara lain:

a) Menurunkan biaya operasional

b) Menentukan biaya prioritas anggaran terhadap input yang langsung berkaitan dengan proses belajar mengajar.

c) Meningkatkan kapasitas pemakaian ruang kelas, dan fasilitas belajar lainnya

d) Meningkatkan kualitas Proses Belajar Mengajar

e) Meningkatkan motivasi kerja guru

f) Memperbaiki rasio guru dan siswa

\section{Efisiensi Eksternal}

Efisiensi eksternal sering dihubungkan dengan metode cost benefit analysis, yakni rasio antara keuntungan finansial sebagai hasil pendidikan dengan seluruh biaya yang dikeluarkan untuk proses pendidikan. Analisis efisiensi eksternal berguna untuk menentukan kebijakan dalam mekanisme pengalokasian biaya pendidikan atau distribusi anggaran kepada seluruh bagian-bagian pendidikan.

Adapun upaya-upaya peningkatan efisiensi pembiayaan pendidikan seperti yang dirumuskan Fattah (2006:43), sebagai berikut:

a) Pemerataan kesempatan memasuki sekolah (equality of acces)

b) Pemerataan untuk bertahan disekolah (equality of survival)

c) Pemerataan kesempatan untuk memperoleh keberhasilan dalam belajar (equality of output) 
d) Pemerataan kesempatan menikmati manfaat pendidikan dalam kehidupan masyarakat (equality of outcome).$^{35}$

\section{E. Penganggaran Biaya Pendidikan}

Penganggaran adalah kegiatan atau proses penyusunan anggaran (budget). Anggaran merupakan rencana operasional yang dinyatakan secara kualitatif dalam bentuk satuan uang yang digunakan sebagai pedoman untuk melaksanakan kegiatan-kegiatan lembaga dalam kurun waktu tertentu. Oleh karena itu kegiatan-kegiatan yang akan dilaksanakan oleh suatu lembaga tercermin dalam sebuah anggaran.

Anggaran pada dasarnya terdiri dari pemasukan dan pengeluaran. Sisi penerimaan atau perolehan biaya dalam anggaran ditentukan oleh besarnya dana yang diterima oleh lembaga dari setiap sumber dana. Biasanya dalam pembahasan pembiayaan pendidikan, sumber-sumber biaya dibedakan dalam tiap golongan pemerintah, orang tua, masyarakat dan sumber-sumber lainnya. Sedangkan pada sisi pengeluaran terdiri atas alokasi besarnya biaya pendidikan untuk setiap komponen yang harus dibiayai.

\section{Prinsip Penyusunan Anggaran}

Ketika anggaran berfungsi sebagai alat dalam perencanaan maupun pengendalian, maka anggaran harus disusun berdasarkan prinsip-prinsip sebagai berikut:

a. Adanya pembagian wewenang dan tanggung jawab yang jelas dalam sistem manajemen dan organisasi

b. Adanya sistem akutansi yang memadai dalam melaksanakan anggaran

c. Adanya penelitian dan analisis untuk menilai kinerja organisasi

d. Adanya dukungan dari pelaksana mulai dari tingkat atas sampai yang paling bawah.

\section{Tahapan Penyusunan Anggaran}

Sistematika tahapan-tahapan dalam prosedur penyusunan suatu anggaran dijabarkan sebagai berikut:

a. Mengidentifikasi kegiatan-kegiatan yang akan dilakukan selama periode anggaran

b. Mengidentifikasi sumber-sumber yang dinyatakan dalam uang, jasa dan barang.

c. Semua sumber dinyatakan dalam bentuk uang, sebab anggaran pada dasarnya merupakan pernyataan finansial.

d. Memformulasikan anggaran dalam bentuk format yang telah disetujui dan dipergunakan oleh instansi tertentu.

e. Menyusun usulan anggaran untuk memperoleh persetujuan dari pihak yang berwenang

f. Melakukan revisi usulan anggaran

g. Persetujuan revisi usulan anggaran

\footnotetext{
${ }^{35}$ Fattah, Nanang, Dr, Ekonomi \& Pembiayaan Pendidikan, (Bandung: PT Remaja Rosdakarya, 2004)
} 


\section{h. Pengesahan anggaran}

Mekanisme penyusunan anggaran dalam organisasi skala kecil biasanya disusun oleh staf pimpinan atau atasan dari suatu bagian. Sedangkan dalam organisasi dengan skala besar, penyusunan anggaran diserahkan kepada bagian, seksi atau komisi anggaran yang secara khusus merancang anggaran. ${ }^{36}$

\section{Bentuk Desain Anggaran}

a. Anggaran Butir per Butir (line item budget)

Bentuk anggaran yang paling sederhana dan banyak digunakan. Dalam bentuk ini, setiap pengeluaran dikelompokkan berdasarkan kategori-kategori, misalnya gaji, upah, honor menjadi satu kategori atau satu nomer atau butir. Sedangkan perlengkapan, sarana, material dengan butir tersendiri.

b. Anggaran Program (program budget system)

Bentuk ini dirancang untuk mengidentifikasi biaya dalam setiap program. Pada biaya per butir dihitung berdasarkan jenis butir (item) yang akan dibeli, sedangkan pada anggaran program biaya dihitung berdasarkan jenis program.

c. Anggaran Berdasarkan Hasil (performance budget)

Bentuk anggaran ini menekankan hasil performance dan bukan pada detail rincian dari alokasi anggaran. Pekerjaan akhir dalam suatu program dipecah dalam bentuk bahan kerja dan unit hasil yang dapat diukur. Hasil pengukuranya dipergunakan untuk menghitung besaran dana dan tenaga yang dipergunakan untuk mencapai suatu program.

d. Sistem Perencanaan Penyusunan Program dan Penganggaran (planing programming budgeting system)

Merupakan kerangka kerja dalam perencanaan dengan mengorganisasikan informasi dan menganalisisnya secara sistematis. Setiap tujuan suatu program dinyatakan dengan jelas, baik jangka pendek maupun jangka panjang dalam sistem PPBS. Dalam proses ini data tentang biaya, keuntungan, kelayakan suatu program disajikan secara lengkap sehingga pengambilan keputusan dapat menentukan pilihan program yang dianggap paling menguntungkan.

\footnotetext{
${ }^{36}$ Tim Pengelola BOS. 2009. Buku Panduan Bantuan Operasional Sekolah. Depdiknas: Dirjen Dikdasmen.
} 


\section{BAB III \\ PROSEDUR PERENCANAAN DAN PENGELOLAAN ANGGARAN PENDIDIKAN}

\section{A. Pengertian Perencanaan Anggaran Di Dalam Suatu Lembaga Pendidikan}

Dalam buku dasar pengajaran manajemen, sesuai dengan makna anggaran (budget), ada tahap perencanaan dasar. Anggaran dapat diartikan sebagai rencana operasional untuk suatu kegiatan atau proyek yang berisi pengeluaran terperinci untuk periode tertentu. ${ }^{37}$

Pendanaan dan pemasukkan adalah sumber daya yang secara langsung mendukung efektivitas dan efisiensi manajemen pendidikan. Ini lebih jelas dalam implementasi manajemen sekolah. Ini membutuhkan kemampuan sekolah untuk merencanakan, mengimplementasikan, mengevaluasi, dan memelihara pengelolaan data yang transparan untuk masyarakat dan pemerintah.

Dalam organisasi pendidikan, pembiayaan dan keuangan merupakan potensi yang sangat penting dan merupakan bagian integral dari studi perencanaan pendidikan. Komponen finansial dan finansial dari institusi pendidikan adalah komponen produksi yang menentukan implementasi kegiatan dalam proses implementasi institusi pendidikan, yang berarti bahwa setiap program yang akan dilaksanakan harus memerlukan anggaran kelembagaan mengurangi biaya keuangan. Oleh karena itu, anggaran kelembagaan, atau komponen keuangan dan keuangan, harus dikelola dengan cara sebaik mungkin. Sehingga anggaran institusi saat ini dapat digunakan secara optimal untuk mendukung pencapaian pendidikan.

Sumber daya keuangan dan keuangan dalam lembaga pendidikan dapat dibagi menjadi tiga sumber:

1. Pemerintah, pemerintah pusat dan daerah, baik negeri maupun swasta, dikhususkan untuk lembaga pendidikan.

2. Orang tua atau siswa.

3. Perusahaan.

Biaya yang dikeluarkan dalam anggaran suatu lembaga pendidikan meliputi, antara lain, biaya rutin yang dikeluarkan dari tahun ke tahun, seperti gaji guru dan staf lembaga pendidikan, biaya operasi, biaya pemeliharaan bangunan dan fasilitas, bahan pendidikan, biaya konstruksi gedung, dan lain-lain.

Laporan keuangan organisasi dalam komponen keuangan harus diimplementasikan secara memadai dan komprehensif, dimulai dengan persiapan laporan keuangan, penggunaan dan pengawasan sesuai dengan aturan dan peraturan yang berlaku, sehingga seluruh anggaran dapat digunakan secara efisien, efektif dan bebas dari korupsi. ${ }^{38}$

Menurut Jones dalam buku manajemen sekolah Dr. E. Muliasa, M.P.d. Fungsi manajemen anggaran Badan dibagi menjadi tiga fase, termasuk perencanaan keuangan, implementasi dan evaluasi. Komponen utama manajemen anggaran meliputi,

37 Nanang Fattah, Landasan Manajemen Pendidikan, PT Remaja Rosdakarya, Bandung, 1996, hlm. 68

38 E. Mulyasa, Manajemen berbasis sekolah, PT Remaja Rosdakarya, Bandung, Mei 2004. hlm 47-48 
1. Prosedur anggaran,

2. Prosedur akutansi keuangan,

3. Pembelanjaan,

4. Prosedur investasi

5. Prosedur pemeriksaan. ${ }^{39}$

Masalah penting dalam penganggaran adalah bagaimana menggunakan sumber daya secara efisien. Epidemi adalah alasan mengapa anggaran membutuhkan proses bertahap. Langkah-langkah yang harus diambil adalah sebagai berikut:

1. Identifikasi kegiatan yang akan dilakukan selama periode anggaran.

2. Identifikasi sumber kas, mesin dan bahan yang dinyatakan.

3. Sumber dinyatakan dalam uang, karena anggaran pada dasarnya adalah laporan keuangan.

4. Merumuskan anggaran dalam format yang disepakati.

5. Upaya untuk mendapatkan wewenang (pengambilan keputusan) pada tahap ini dikompromikan melalui pertemuan yang perlu dipertimbangkan secara obyektif dan subyektif.

Saat merancang anggaran ada beberapa cara:

1. Anggaran artikel demi artikel.

Bentuk penganggaran ini memfasilitasi kontrol pengeluaran tetapi tidak membantu dalam pengambilan keputusan.

2. Program penganggaran

Modul ini menyoroti tujuan spesifik yang ditetapkan dalam deklarasi fungsi. Oleh karena itu, penganggaran berbasis program memerlukan seleksi objektif dan alokasi sumber daya berdasarkan analisis sistematis.

Rencanakan tujuan, menjembatani kesenjangan antara apa yang Anda miliki sekarang dan apa yang Anda inginkan di masa depan. Perbedaan antara saat ini dan masa depan menyediakan bahan untuk merancang definisi objektif yang ingin dicapai dalam pendidikan. parasit, perencanaan pendidikan sebagai kegiatan kompleks berdasarkan kompleksitas masalah pendidikan.

Demikian juga, anggaran diperlukan sebagai perumusan rencana keuangan, fungsi untuk menggunakan sumber daya secara efisien, dapat digunakan sebagai alat untuk memantau dan mengevaluasi tingkat efektivitas dan efisiensi kegiatan tertentu. ${ }^{40}$

39 Ibid, hlm 49

40 Nanang Fattah, Op.Cit, hlm. 68-69 


\section{B. Perencanaan Anggaran Lembaga Pendidikan}

\section{Penyusunan Anggaran Sekolah}

Sehubungan dengan proses anggaran, dalam bukunya tentang manajemen pendidikan, Lipham mengungkapkan empat fase utama dari kegiatan berikut:

a. Perencanaan anggaran.

b. Siapkan anggaran.

c. Kelola implementasi anggaran.

d. Mengevaluasi implementasi anggaran.

\section{Proses anggaran belanja di sekolah}

Ada tiga jenis pendekatan anggaran yang biasa digunakan di sekolah;

a. Pendekatan Comparative

1) Bandingkan laporan atau catatan hasil dengan pengeluaran antara anggaran satu tahun lalu dan anggaran tahun berikutnya.

2) Keputusan anggaran didasarkan pada peningkatan lebih lanjut dari satu hal ke hal lainnya.

b. Pendekatan The planning programming budgeting evaluating system

1) Jelaskan tujuan program dalam struktur tertentu.

2) Jelaskan nilai dari setiap alternatif.

3) Menjelaskan biaya implementasi dan evaluasi setiap program.

c. Pendekatan Function

1) Proses penganggaran dimulai dengan tujuan sekolah.

2) Pendekatan ini mencakup elemen yang terkandung dalam pendekatan kompetitif dan PPBES. ${ }^{41}$

Anggaran adalah kegiatan atau proses penyusunan anggaran (budget). Anggaran adalah rencana operasi yang secara kuantitatif dinyatakan dalam bentuk unit moneter yang digunakan sebagai panduan untuk melakukan kegiatan kelembagaan selama periode waktu tertentu. Oleh karena itu, anggaran mencerminkan kegiatan yang akan dilakukan oleh lembaga.

Anggaran adalah langkah positif menuju implementasi rencana yang telah disiapkan. Kegiatan ini melibatkan kepemimpinan masing-masing unit organisasi. Pada dasarnya, anggaran adalah negosiasi atau perjanjian antara pemimpin senior dan tingkat bawah untuk menentukan ukuran anggaran. Hasil akhir dari negosiasi adalah pernyataan pengeluaran yang diharapkan dan pendapatan untuk setiap sumber data. ${ }^{42}$

41 Fatah Syukur, Manajemen Pendidikan, PT. Pustaka Rizki Putra, Semarang, 2011, hlm. 114-116

42 Nanang Fattah, "Ekonomi Dan Pembiayaan Pendidikan", Rosdakarya, Bandung, 2004,hlm. 47 


\section{Karakteristik Suatu Anggaran Sekolah}

Anggaran pada dasarnya adalah dua sisi, yaitu sisi pendapatan dan sisi pengeluaran. Pendapatan atau pembagian biaya ditentukan oleh jumlah dana yang diterima oleh lembaga dari masing-masing sumber pendanaan. Secara umum, dalam hal pendanaan pendidikan, sumber daya pendaftaran dibedakan untuk setiap kelompok, pemerintah, masyarakat, orang tua dan sumber lainnya.

Bagian pengeluaran terdiri dari semua penerimaan yang diterima, yang sebagian digunakan untuk membiayai kegiatan administrasi, administrasi, pendidikan dan infrastruktur, dan lainnya. ${ }^{43}$

\section{Fungsi Anggaran Sekolah}

Selain anggaran sebagai alat perencanaan dan kontrol, ini juga merupakan alat manajemen bagi lembaga untuk menempatkan organisasi pada posisi yang kuat dan lemah. Oleh karena itu, keanggotaan juga dapat menjadi titik referensi bagi keberhasilan organisasi dalam mencapai tujuannya. Selain itu, anggaran juga dapat digunakan sebagai alat untuk mempengaruhi dan memotivasi para pemimpin atau manajer dan karyawan untuk bertindak secara efektif dalam mencapai tujuan kelembagaan.

a. Anggaran juga berfungsi sebagai alat perencanaan yang, antara lain, digunakan untuk:

1) Merumuskan tujuan dan sasaran kebijakan sesuai dengan visi dan misi yang dinyatakan.

2) Rencanakan berbagai program dan kegiatan untuk mencapai tujuan organisasi dan merancang sumber pendanaan alternatif.

3) Mengalokasikan sumber daya anggaran untuk berbagai program dan kegiatan yang disediakan.

4) Tentukan indikator kinerja dan tingkat pencapaian strategi.

b. Anggaran berfungsi sebagai kontrol, digunakan, antara lain:

1) Periksa efisiensi pengeluaran Anda

2) Batasi kekuatan dan otoritas lembaga pendidikan.

3) Mencegah pengeluaran yang berlebihan dan tujuan yang salah dalam alokasi anggaran di lembaga pendidikan.

4) Memantau kondisi keuangan dan implementasi program lembaga pendidikan.

c. Anggaran adalah alat fiskal utama yang digunakan untuk menstabilkan anggaran lembaga dan mendorong kemajuan lembaga pendidikan.

d. Penganggaran adalah cara mengoordinasikan unit kerja dalam persiapan anggaran.

e. Estimasi dapat digunakan sebagai alat penilaian kinerja.

f. Anggran dapat digunakan sebagai alat untuk memotivasi manajemen pendidikan untuk bekerja secara ekonomi, efektif dan efisien.

${ }^{43}$ Ibid, hlm. 48 
g. Anggaran juga dapat menjadi alat untuk menciptakan ruang publik, yang berarti bahwa semua jaringan pendidikan dapat memberi manfaat bagi semua bidang pendidikan. ${ }^{44}$

\section{Prinsip-prinsip Anggaran Sekolah}

Prinsip-prinsip anggaran adalah sebagai berikut:

a. Ada pembagian kekuasaan dan tanggung jawab yang jelas dalam sistem manajemen dan organisasi.

b. Ada sistem akuntansi yang memadai dalam implementasi anggaran.

c. Ada penelitian dan analisis untuk mengevaluasi kinerja organisasi.

d. Ada dukungan dari eksekutif yang bergerak dari atas ke bawah.

Masalah penting dalam anggaran adalah bagaimana menggunakan dana secara efisien, mengalokasikannya sesuai, pada skala prioritas. ${ }^{45}$

\section{Rencana Anggaran Pendapatan Belanja Sekolah (RAPBS)}

RAPBS harus mengafeksikan asas-asas anggaran berikut ini;

a. Asas ketelitian

b. Asas kedetailan

c. Asas kemerataan

d. Asas transparansi

e. Asas berkala

f. Asas pengindahan

Masalah yang terkait dengan pengaturan RAPBS:

Salah satu implikasi dari penerapan manajemen berbasis sekolah sebagaimana diatur oleh undang-undang tentang sistem pendidikan adalah bahwa kepala sekolah (terutama kepala sekolah) harus mengambil tanggung jawab yang lebih besar dalam proses pengembangan RAPBS. Oleh karena itu, para pemimpin disarankan untuk mengetahui tentang berbagai masalah yang mereka hadapi dalam memenuhi tanggung jawab penting ini. Beberapa masalah yang sering muncul dalam proses menyiapkan RAPBS dijelaskan di bawah ini;

a. Anggaran yang diusulkan didasarkan pada ketersediaan uang dan tidak didukung oleh pengetahuan yang memadai.

b. Penjelasan tidak lengkap tentang pentingnya proposal anggaran untuk meningkatkan pembelajaran siswa.

c. Penurunan anggaran pendidikan dari tahun ke tahun.

d. Kurangnya kapasitas untuk mengevaluasi proposal anggaran.

e. Permintaan untuk membeli produk bermerek atau ancaman sentralisasi anggaran.

44 Udin Syaifudin Sa'ud Dan Abin Syamsuddin Makmun. Perencanaan Pendidikan Suatu Pendekatan Komprensif, Bandung: PT Remaja Rosdakarya. 2007, hlm 261-263

45 Nanang Fattah, Op.Cit hlm. 49-50 
f. Kurangnya orientasi, komunikasi dan konsultasi dengan pihak terkait. ${ }^{46}$ Strategi untuk menyiapkan RAPBS (rencana pengeluaran sekolah):

a. Model keputusan yang terintegrasi, koheren, dan terpadu untuk setiap komponen.

b. Menentukan dan mengembangkan tujuan kelembagaan yang ditetapkan dalam tujuan, program dan prioritas jangka pendek, menengah dan menengah dari alokasi sumber daya pendidikan.

c. Pilih jenis keterampilan, kemampuan, dan pengetahuan yang mungkin dibutuhkan masyarakat di masa depan.

d. Menanggapi dengan cepat semua peluang dan ancaman, kelemahan, dan keunggulan institusi pendidikan.

e. Mengembangkan komitmen semua pihak, siswa, orang tua, masyarakat, pemerintah, unit Departemen Pendidikan dan Kebudayaan dengan sekolah internal (siswa-kepala sekolah) untuk bersama-sama meningkatkan kualitas sekolah.

f. Tentukan tingkat kontribusi setiap kontribusi pendidikan yang terkait dengan kualitas pendidikan atau kinerja siswa (efisiensi internal) dan tingkat kelulusan (kompetensi eksternal). ${ }^{47}$

\section{Critical Thinking}

Pendidikan nasional kita saat ini membahas masalah-masalah seperti peningkatan kualitas, kesempatan yang setara, kendala anggaran yang tersedia, dan sumber daya komunitas profesional yang tidak dihormati oleh prinsip-prinsip pendidikan sebagai tanggung jawab bersama antara pemerintah, masyarakat dan orang tua

Dengan meningkatkan kualitas rakyat Indonesia, pemerintah bukanlah sistem yang terpisah dari sektor swasta dan masyarakat. Hubungan antara pemerintah, masyarakat dan individu merupakan mata rantai yang tidak terpisahkan dalam fungsinya untuk meningkatkan kesetaraan dan kualitas pendidikan.

Jika kita ingin menempatkan pendidikan dalam pendidikan kehidupan nasional dalam konteks masyarakat sipil, harus ada investasi yang signifikan dalam memperkuat sistem pendidikan nasional. Selain itu, itu juga membutuhkan upaya yang sangat serius untuk memperkuat pendidikan sebagai jalur utama kekuatan bukan hanya sebagai peran konstitusional. Namun, ini menanggapi tantangan nyata pengembangan masyarakat secara internal dalam peraturan global.

Anggaran bukan hanya anggaran, mereka awalnya direncanakan sehingga semua anggaran yang ada akan mematuhi program, tetapi tidak semua perencanaan anggaran seratus persen. Karena itu, untuk mengatasi kekurangannya, perencanaan anggaran tidak

46 Jamal Ma'mur Asmani, Tips Aplikasi Manajemen Sekolah, Diva Press, Yogyakarta,2010, hlm. 216-249.

47 Nanang Fattah, Op.Cit, Hlm. 53-55 
diperlukan. Dalam hal ini, harus ada output yang digunakan sebagai output jika anggaran awal melebihi target yang ada.

\section{Pengertian pengelolaan anggaran lembaga pendidikan}

Pengelolaan anggaran secara garis besar dapat dikelompokan ke dalam dua kegiatan sebagai berikut;

Pertama, penerimaan anggaran untuk pendidikan sekolah dari sumber pendanaan harus dicatat sesuai dengan prosedur manajemen sesuai dengan alokasi yang disetujui. Sementara itu, sumber pendanaan termasuk anggaran reguler, anggaran pembangunan, anggaran dukungan pendidikan, dana publik, donor dan banyak lagi. Kedua, pengeluaran, yang merupakan dana yang berasal dari berbagai sumber, harus digunakan secara efektif dan efisien. Artinya, pengadaan dana harus didasarkan pada kebutuhan yang telah disesuaikan dengan perencanaan pendanaan sekolah. ${ }^{48}$

Pendapatan dan pengeluaran dalam mengelola anggaran dilakukan melalui kegiatan administrasi, khususnya pendaftaran dan uang saku yang digunakan untuk mendanai program pendidikan untuk mendapatkan informasi tentang manajemen keuangan yang bertanggung jawab.

Dalam pengelolaan keuangan pendidikan, ada dua kegiatan penting, yaitu: pengumpulan data dan pelaporan pendanaan pendidikan dan akuntansi pelaksanaan anggaran pendidikan.

Kegiatan pendidikan untuk pengumpulan data dan pelaporan keuangan meliputi identifikasi dan pengukuran data keuangan, klasifikasi data keuangan dan komunikasi data keuangan oleh pengguna. Proses ini dapat digambarkan sebagai berikut:

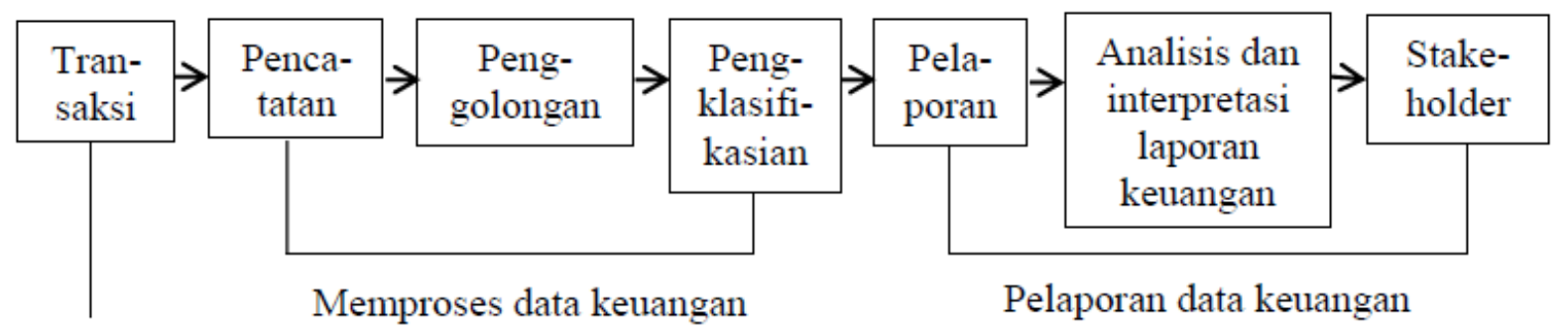

Identifikasi dan Pengukuran

Gambar Proses Pendataan dan Pelaporan Keuangan Pendidikan ${ }^{49}$

Dari gambar di atas, Anda dapat melihat bahwa proses pengumpulan data dan laporan keuangan tentang pendidikan dimulai dengan mengidentifikasi dan mengukur data keuangan. Dalam kegiatan ini, setiap transaksi keuangan pendidikan dicatat secara kronologis dan sistematis selama periode waktu dalam sebuah buku atau dalam nomor yang

48 Suharsimi Arikunto dan Lia Yuliana, Manajemen Pendidikan (Yogyakarta: Aditya Media, 2012), hlm. 240

49 Ibid, hlm. 138 
disebut majalah. Setiap catatan harus didukung oleh dokumen keuangan seperti catatan, faktur, kwitansi, dll. Langkah selanjutnya adalah mengolah data keuangan pendidikan. Kegiatan-kegiatan ini termasuk pendaftaran, penggabungan, dan ringkasan. Log transaksi adalah kumpulan data historis yang kemudian diklasifikasikan ke dalam kategori tertentu untuk mengurangi presentasi. Meskipun ringkasan adalah presentasi informasi yang telah diklasifikasikan dalam laporan. Proses terakhir adalah melaporkan data pendidikan keuangan. Data keuangan pendidikan yang telah dicatat, dikumpulkan dan diringkas harus disajikan kepada pihak yang berkepentingan. Laporan harus dibuat sesuai dengan hukum dan peraturan yang berlaku. ${ }^{50}$

Kegiatan administrasi keuangan lainnya adalah akuntansi, pelaksanaan anggaran pendidikan. Akuntansi adalah kegiatan yang berkaitan dengan penerapan akuntansi teknis, yang terdiri dari pendaftaran, klasifikasi dan ringkasan transaksi keuangan. Selain itu, akuntansi juga melakukan inspeksi, persiapan laporan keuangan, interpretasi laporan, dll.

Oleh karena itu, diketahui bahwa dalam pelaksanaan pembiayaan terdapat berbagai kegiatan yang berkaitan dengan pengumpulan data keuangan dan akuntansi transaksi keuangan. Dalam praktiknya, kedua kegiatan itu saling berkaitan erat. Itu pengumpulan data dan laporan keuangan berasal dari buku-buku yang telah dibuat.

50 Ibid, hlm. 139 


\section{BAB IV \\ PENGELOLAAN DAN PENGALOKASIAN ANGGARAN PENDIDIKAN}

\section{A. Pengelolaan Keuangan Pendidikan}

Telah tercantum pada Undang-undang nomor 20 tahun 2003 bahwa dana pendidikan adalah seluruh pengeluaran yang berupa sumber daya (input) baik berupa barang maupun berupa uang yang ditujukan untuk menunjang kegiatan proses belajar mengajar.

Pada penyelenggaraan di sekolah sangatlah penting adanya biaya pendidikan, karena suatu biaya pendidikan adalah salah satu komponen instrumental (instrumental input) yang sangat penting. ${ }^{51}$ Menurut Mulyasa, "Keuangan dan pembiayaan merupakan salah satu sumber daya yang secara langsung menunjang efesiensi dan efektifitas pengelolaan pendidikan". ${ }^{52}$ Definisi biaya menurut Supriyono biaya adalah pengorbanan ekonomis yang dibuat untuk memperoleh barang atau jasa. Secara bahasa, biaya (cost) dapat diartikan sebagai pengeluaran, dalam istilah ekonomi biaya pengeluaran dapat berupa uang atau bentuk moneter lainnya. Menurut Dedi Supriadi dalam bukunya mendefinisikan biaya sebagai semua jenis pengeluaran yang berkenaan dengan penyelenggaraan pendidikan baik dalam bentuk uang, barang, dan tenaga (yang dapat dihargakan dengan uang) ${ }^{53}$ Sedangkan menurut Harsono, "Biaya pendidikan adalah semua pengeluaran yang memiliki kaitannya langsung dengan penyelenggaraan pendidikan".

Biaya pendidikan memliki beberapa jenis. Berikut adalah biaya pendidikan menurut sumbernya dapat digolongkan menjadi empat jenis, yaitu :

1. Biaya pendidikan dari pemerintah.

2. Biaya pendidikan dari masyarakat orang tua/wali siswa.

3. Biaya pendidikan dari masyarakat bukan orang tua/wali siswa, misalnya adalah sponsor dari lembaga keuangan dan perusahaan.

4. Lembaga pendidikan itu sendiri. ${ }^{54}$

Adanya biaya tentu harus dapat mengelola dengan baik, maka dari itu harus ada pengelolaan dana pendidikan. Pengelolaan dana pendidikan ialah suatu proses perencanaan, pelaksanaan, dan evaluasi pengalokasian biaya untuk segala macam program dan segala macam kegiatan pendidikan karakter yang dituangkan dalam Rencana Kegiatan Anggaran Sekolah (RKAS) dan Rencana Kerja Sekolah (RKS).

Prinsip-prinsip manajemen yang baik yang sesuai dengan prinsip-prinsip MBS dalam pengelolaan dana pendidikan baiknya dilakukan secara terbuka, kerjasama, mandiri, dipertanggung-jawabkan juga partisipasif kepada para masyarakat terhadap sekolah sehingga partisipasi masyarakat dapat meningkat terhadap pendidikan. Hal ini pada dasarnya

\footnotetext{
${ }^{51}$ Dedi Supriadi, Satuan Biaya Pendidikan, (Bandung : Remaja Rosdakarya, 2003), hlm.3.

52 E. Mulyasa, Manajemen Berbasis Sekolah : Konsep, Karakteristik, dan Implementasi, (Bandung Remaja Rosdakarya, 2003), hlm.47.

${ }^{53}$ Dedi Supriadi, Satuan Biaya Pendidikan, (Bandung : Remaja Rosdakarya, 2003), hlm.3.

${ }^{54}$ Harsono, Pembiayaan Pendidikan, (Yogyakarta : Surayajaya Pres, 2007), hlm.9
} 
adalah termasuk nilai-nilai karakter dalam pengelolaan sekolah. Pada dasarnya, sekolah yang telah memiliki karakter adalah sekolah yang telah melakukan MBS. ${ }^{55}$

Mulyasa menjelaskan bahwa : "Dalam MBS, sekolah dituntut secara mandiri menggali, mengalokasikan, menentukan prioritas, mengendalikan dan mempertanggungjawabkan sumber daya, baik kepada pemerintah ataupun masyarakat." .56

Di atas telah dipaparkan beberapa pendapat, sesuai beberapa pendapat di atas, maka dapat disimpulkan bahwa, pengelolaan dana pendidikan ialah suatu kegiatan perencanaan, pelksanaan, dan evaluasi alokasi pengeluaran secara terbuka, mandiri, akuntabilitas, kerjasama, dan partisipasi yang dapat menentukan terselenggaranya proses pendidikan karakter dengan memanfaatkan sumber daya yang ada, baik berupa uang ataupun bukan uang yang telah tertuang dalam RKAS dan RKS untuk tercapainya tujuan pendidijan yang telah ditetapkan.

\section{B. Pengalokasian Dana Pendidikan}

Selain dana pendidikan sangatlah penting, harus mengingat bahwa adanya dana juga harus dialokasikan. Pengalokasian tersebut haruslah dilakukan dengan baik dan sesuai. Pengalokasian ialah sebuah rencana untuk penetapan jumlah dan prioritas uang yang ada yang dimana akan digunakan dalam pelaksanaan berbagai kegiatan pendidikan di sekolah. ${ }^{57}$

Dana pendidikan dapat dialokasikan untuk beberapa kebutuhan. Berikut adalah alokasi keuangan Sekolah Swasta Negeri maupun Sekolah Negeri :

1. Mengalokasikan dana untuk pembangunan fisik dan non fisik.

2. Mengalokasikan dana untuk kegiatan rutin, misalnya kegiatan mengajar dan belajar,

kebutuhan rumah tangga, pembinaan kesiswaan, dan belanja pegawai,.

Ada dasar-dasar yang biasanya dipakai untuk menhgalokasikan dana pada suatu unit pendidikan. Dasar-dasar tersebut yaitu menggunakan komponen ruang belajar, guru, dan siswa. Selain dari komponen ini ada juga pengalokasian dana berdasarkan bobot tujuantujuan suatu pendidikan, dan angka sesuai dengan banyaknya angka partisipasi siswa.

1. Pengalokasian Dana atas Dasar Siswa

Pada pengalokasian ini memakai dasar atas banyaknya jumlah siswa yang terdaftar. Jumlah siswa yang terdaftar di suatu sekolah dapat dihitung pada tiap awal tahun ajaran, pertengahan tahun ajaran, atau pada akhir tahun ajaran. Penata usahanya menggunakan pelaporan sasaran. ${ }^{58}$

2. Pengalokasian Dana atas Dasar Guru

Pada pengalokasian ini, untuk guru patut diperhatikan karena karakteristik pengajar/guruy yang berbeda-beda. Ada guru yang pendidikan dasar, ada yang

\footnotetext{
55 Zainal Aqib dan Sujak, Pembiayaan Pendidikan, (Jakarta : Gaung Persada Press, 2011), hlm.31.

${ }^{56}$ E. Mulyasa, Manajemen Berbasis Sekolah : Konsep, Karakteristik, dan Implementasi, (Bandung : Remaja Rosdakarya, 2003), hlm.24.

57 Depdiknas, 2009.

${ }^{58}$ Martin, Manajemen. Pembiayaan Pendidikan Konsep dan Aplikasi, (Jakarta : Raja Grafindo Persada), 2014), hlm 123
} 
pendidikan menengah, dan ada yang pendidikan tinggi. Guru juga dibagi berdasarkan guru kelas dan bidang studi, menurut tempat tugas, atau menurut gabungan dari penggolangan tersebut.

3. Pengalokasian Dana atas Dasar Ruang Belajar

Dana berupa modal dalam pendidikan sering dinyatakan sebagai rata-rata pembuatan ruang belajar. Dengan demikian, pengeluaran modal sering dialokasikan atas dasar jumlah tertentu per ruang belajar.

4. Pengalokasian Dana atas Dasar Tujuan Pendidikan

Yang termasuk dalam pengalokasian dana ini adalah adanya suatu keragaman dalam jumlah dana yang dapat digunakan untuk mencapai tujuan-tujuan yang berbeda. Seperti macam-macam dalam jumlah dana yang dapat disiapkan dan dicapai dengan menggunakan pembobotan dalam satuan pendidikan.

5. Pengalokasian Dana atas Dasar Peningkatan Angka Partisipasi

Angka partisipasi yaitu perbandingan antara jumlah siswa dengan anak usia sekolah pada suatu wilayah tertentu. terdapat dua angka partisipasi yaitu Angka Partisipasi Murni (APM) dan Angka Partisipasi Kasar (APK). APM adalah angka perbandingan antara jumlah siswa usia tertentu terhadap jumlah penduduk usia tertentu pada suatu wilayah. Misalnya, perbandingan antara jumlah siswa usia 7-12 tahun terhadap jumlah penduduk usia 7-12 tahun di suatu kecamatan. APK adalah perbandingan antara jumlah siswa suatu jenjang pendidikan tertentu terhadap jumlah penduduk usia yang relevan dengan siswa pada jenjang pendidikan tersebut. Misalnya, perbandingan antara jumlah siswa SD terhadap jumlah penduduk terhadap usia 712 tahun di suatu kecamatan. ${ }^{59}$

6. Pengalokasian Dana atas Dasar Pengamatan terhadap Rumus-Rumus Alokasi Keuangan

Rumus keuangan hanya dapat dipakai bersamaan dengan tindakan lainnya. Jika rumus dimaksudkan sebagai penyediaan bahan yang bersamaan untuk pelajaran baru, program pelatihan para guru dan perangsang bagi mereka untuk mendaftarkan diri pada keahlian mengajar yang baru tersebut. ${ }^{60}$

Pembiayaan suatu pendidikan tidak hanya berkaitang tentang analisis sumber-sumber dananya, melainkan juga tentang penggunaan dana secara efisien. Jika efisien sistem pendidikan bertambah, maka akan semakin berkurang biaya yang dibutuhkan. ${ }^{61}$ Segala pemakaian dana pendidikan oleh satuan pendidikan dilakukan melewati mekanisme yang telah diaur pada anggaran rumah tangga satuan pendidikan dan aggaran dasar. ${ }^{62}$

\footnotetext{
${ }^{59}$ Ibid, hlm 124.

${ }^{60}$ Ibid, hlm 125.

${ }^{61}$ Zymelman, Financing and Efficiency in Education: Referent for Administration and Policy Making, (Boston the Nimrod Press, 1973).

${ }^{62} \mathrm{PP}$ no 48 tahun 2008 pasal 69 ayat 3.
} 


\section{Tujuan Pengalokasian dan Pengelolaan Dana Pendidikan}

Dalam pengalokasian dan pengelolaan dana pendidikan pasti memiliki maksud dan tujuan. Beberapa tujuan tersebut adalah sebagai berikut :

1. Meningkatkan efisiensi dan efektivitas dalam pemakaian dana sekolah.

2. Meningkatkan transparasi dan juga akuntabilitas dana sekolah.

3. Agar terjaminnya dana sekolah yang telah tersedia, yaitu agar dapat digunakan untuk keperluan sehari-hari di sekolah dan memakai kelebihan dari dana tersebut sebagai investasi.

4. Memelihara barang-barang yang telah tersedia di sekolah.

5. Meminimalkan kasus penyalahgunaan anggaran sekolah.

6. Menjaga agar peraturan-peraturan yang telah dibuat serta praktik penerimaan, pencatatan, dan pengeluaran uang diketahui dan dilaksanakan. ${ }^{63}$

\section{Pengelolaan Anggaran Pendidikan Islam Pada Masa Klasik}

Pola pengelolaan dana pendidikan pada masa klasik dilakukan melalui dua cara yaitu:

\section{Sentralisasi}

Maksud sentralisasi disini adalah dana pendidikan yang direncanakan dan dikelola oleh birokrat (pemegang otoritas kekuasaan), bukan oleh lembaga pendidikan yang bersangkutan. Menurut sejarah pendidikan Islam, lembaga-lembaga pendidikan formal yang didanai oleh negara, tidak memiliki Otoritas untuk mengatur sumber keuangan yang memang tidak dimilikinya. Semua kebutuhan pendidikan akan dipenuhi oleh pemerintah melalui kas negara atau baitul al-maal. Karenanya eksistensi lembaga pendidikan sangat tergantung dengan kebijakan pemerintah terhadap sektor pendidikan, atau perhatian khalifah atau penguasa terhadap lembaga pendidikan dan ilmu pengetahuansecara umum. Dar al-Hikmi di Cairo yang didirikan oleh Al-Hakim bin Amrillah pada tahun 1004 M. menghabiskan kira-kira 257 dinar setiap tahun dari kas negara guna beragam keperluan diluar gaji guru dan karyawan. Dana tersebut digunakan untuk membeli kertas, tikar, gaji pemimpin perpustakaan, air, gaji pesuruh, keperluan para pengajar/ulama, perbaikan kain, pintu, menjilid buku, membeli permadani» Sedangkan Ahmad, raja Idzadj, membagi hasil pajak negaranya menjadi tiga bagian, sepertiganya disediakan guna membiayai pendidikan dan pengajaran di sudut-sudut masjid dan di sekolah-sekolah. Waqaf yang digunakan sebagai model pendanaan berbagai lembaga pendidikan Islam ini, juga tidak terlepas dari sistem terpusat (sentralisasi). Pemberi waqaf sering kali menentukan pola pengelolaan harta waqafnya dan pembagian yang jelas dari harta hasil waqaf tersebut dalam dokumen waqaf, tanpa mempertimbangkan kemungkinan-kemungkinan situasi dan kebutuhan

\footnotetext{
${ }^{63}$ Matin, Manajemen Pembiayaan Pendidikan Konsep dan Aplikasi, (Jakarta : Raja Grafindo Persada), 2014).
} 
lembaga pendidikan tersebut di belakang hari. Selain itu mereka sering menentukan diri mereka atau ahli warisnya sebagai penanggung jawab dalam mengelolah harta waqaf tersebut. ${ }^{64}$

2. Desentralisasi

Sistem desentralisasi ini lebih bersifat fleksibel dan partisipatif dibanding sistem sentralisasi. Sistem desentralisasi keuangan pendidikan, merupakan pola manajemen keuangan lembaga pendidikan yang bukan hanya berorientasi pada Kebutuhan Ariel lembaga tersebut dalam segala perubahannya, tapi juga pengelolaannya tidak memiliki otoritas mutlak. Pola desentralisasi ini dapat dibagi menjadi dua bentuk yaitu: Pertama, tradisional. Pada pola tradisional ini dana yang diperoleh biasanya digunakan tanpa perencanaan yang jelas. Beragam kebutuhan operasional pendidikan akan dapat dipenuhi tatkala ada pemasukan dari sumbersumber dana, seperti orang tua siswa, siswa, para dermawan dan para pengajar itu sendiri. tetapi manakala sumber dana kosong maka semua kebutuhan pendidikanpun menjadi tertunda, menunggu setelahadanya sumber dana lagi. Lembaga-lembaga pendidikan non formal banyak yang memakai pola pengelolaan desentralisasi dengan corak tradisional ini.. Salah satu contohnya kuttab yang banyak tersebar diberbagai lokasi, banyak yang diselenggarakan dengan cara sederhana tanpa campur tangan pemererintah dengan roti sebagai pemasukan dana pendidikan ditambah sedikit uang pada masa khatam Al- Qur'an. Para ulama yang menjadikan rumahnya sebagai tempat belajar pun tidak pernah mengelola input sukarela ditangannya dengan perencanaan dan manajemen yang terarah. Para ulama tersebut hanya akan memenuhi kebutuhan operasioual pendidikannya dengan dana yang tersedia, atau ditambah dengan dana dari kantongnya sendiri maupun dari sumbangan tambahan yang dicari. Kedua, Non tradisional. Pola ini merupakan antitesis pola tradisional, dana yang masuk dikelola oleh penyelenggara lembaga pendidikan tersebut, melalui rencana yang terarah sesuai dengan situasi dan kondisi lembaga yang bersangkutan. Sistem waqaf dapat menjadi contoh dalam pola ini. Dalam dokumen waqafnya, pemberi waqaf tidak mengbaruskan dirinya, keluarganya, ataupun orang-orang tertentu diluar pengelola lembaga pendidikan tersebut sebagai pengelola harta waqaf. Dalam dukumen waqaf madrasah Asy-Syamiyah al-jawwaniyyah dicantumkan dengan jelas materi-materi kekayaan waqaf, kebutuhan riel yang akan dipenubinya, dan cara pengelolaan harta tersebut.

\footnotetext{
${ }^{64}$ Rahmawati Rahim, Pola pembiayaan Pendidikan Islam Pada Masa Kalasik, Ta'dib : 01(2012), 76
} 
"Bismillahirrahmanirrahiem..." Adapun barang-barang yang diwaqafkan untuk biayabiaya gedung, para fuqaha dan siswa serta keperluan-keperluan lain ialah semua desa "Bazinah", semua bagian yang diperoleh dari perkebunan "Jirmana", yakni 11,5 bagian dari 24 bagian, semua bagian yang diperoleh dari desa "A-Tinah", yaitu 14 ditambah 7 bagian dari 24 bagian, separuh dari desa "Majidal As-Suwaida", serta seluruh desa "Majidal AlQarjah, sedangkan pembiayaan Sekolah ini adalah: Prioritas untuk gedunggedung sekolah. Untuk para ustadz, dibagikan sekarung gandum, sekarung syair, dan uang perak Nashiriyyah sebanyak 130 dirham. Sepersepuluh dari sisanya untuk honor pengawas (Nazhir) waqaf. 300 dirham uang perak Nashiriyyah digunakan untuk bahan-bahan makanan dan kue-kue untuk nisfu syakban menurut pendapat Nazhir waqaf. Sisanya diberikan kepada para fuqaha, siswa-siswa, muadzin dan pelayan dengan ukuran jumlahnya menurut pendapat kepala sekolah ataupun untuk tidak mendapatkannya sama sekali. ${ }^{65}$

65 Ibid, HIm. 77 


\section{BAB V \\ TANGGUNG JAWAB PEMBIAYAAN PENDIDIKAN}

\section{A. Jaminan Konstitusi Pendanaan Pendidikan}

Pembiayaan dalam institusi atau satuan pendidikan sekolah merupakan proses pendapatan dan sumber daya tersedia yang digunakan untuk mengoperasikan sekolah pada berbagai wilayah geografis dan tingkat satuan pendidikan. ${ }^{66}$ Pendanaan dalam satuan pendidikan ada kaitannya dengan bidang politik pendidikan dan program pembiayaan dari pemeruntah untuk pengoperasonalan sekolah. Istilah yang sering digunakan dalam proses pembiayaan dalam satuan pendidikan adalah school revenues dan capital and current cost. Pembiayaan setiap institusi atau satuan pendidikan berbeda, karena kondisi setiap sekolah berbeda-beda antara sekolah satu dengan sekolah lainnya. Bahkan kondisi dan situasi siswa maupun siswi di sekolah juga berbeda-beda kemampuannya.

Peraturan dan kebijakan mengenai pembiayaan dalam satuan pendidikan telah diatur sebagaimana kemampuan sekolah tersebut. Adanya peraturan dan kebijakan akan mempengaruhi proses pendapatan sumber daya dan cara mengalokasiannya. Adanya kajian dan peraturan kebijakan yang berbeda setiap institusi atau satuan pendidikan akan menmapakkan akibat dari kenijakan pembiayaan yang ada, yaitu:

1. Kebijakan mengenai guru dan waktu yang disediakan dalam mendidik

2. Kebijakan mengenai proses pengajaran yang akan diberikan setiap guru dalam proses pembelajaran

3. Kebijakan mmengenai penanggungjawab dana pendidikan siswa atau siswi

4. Kebijakan mengenai sistem dari pemerintah yang cocok untuk pendanaan dalam satuan pendidikan tersebut guna proses pembelajaran

Akibat dari keempat pokok pembahasan terdapat dua pembahasan yang perlu dijawab, yaiyu:

1. Bagaimana cara setiap institusi atau satuan pendidikan mendapatkan sumber daya

2. Bagaimana cara mengalokasikan pada setiap institusi atau satuan pendidikan yang setiap kondisi dan situasi setiap institusi atau satuan pendidikan berbeda-beda

J. Wiseman dalam bukunya membahas tigas aspek mengenai keikut sertaan pemerintah dalam melibatkan diri dalam permasalahan dalam pendanaan setiap pendidikan:

1. Pendidikan sebagai salah satu alat dalam perdagangan serta kebutuhan untuk investasi dimasa mendatang mengenai sumber daya manusia atau human capital.

2. Hak orangtua dalam mendanai pendidikan anak terkait dengan sekolah yang nantinya akan berdampak baik pada anak secara keseluruhan .

\footnotetext{
${ }^{66}$ Rida Fironika, Jurnal Volume 02, Nomor 01 Pembiayaan Pendidikan Di Indonesia, http://jurnal.unissula.ac.id/index.php/pendas/article/view/755/632, 18 januari 2016.

${ }^{67}$ Nanang Fattah, Standar Pembiayaan Pendidikan, (Bandung: Remaja Rosdakarya, 2012), h. 3.
} 
3. Adanya pengaruh politik dalam bidang pendidikan, selain itu adanya faktor ekonomi yang nantinya juga mempengaruhi bidang pendidikan.

Pendanaan yang dikeluarkan wali murid untuk mendanai pendidikan siswa ataupun siswi yang didalamnya juga termasuk pendanaan probadi. Jones berpendapat, "In the context of education these include tuitions, fees and other expenses paid for by individuals".

Hal itu dijelaskan bahwa biaya pribadi merupakan pendanaan untuk kegiatan sekolah yang dibayarkan oleh setiap wali murid atau keluarga murid guna mendapatkan fasilitas dalam proses pembelajaran.

Institusi maupun satuan pendidikan dalam tahap mengembangkan akan membutuhkan dana lebih besar guna keperluan sarana dan prasarana yang nantinya digunakan dalam proses pembelajaran. Selain itu, pendanaan yang diperlukan untuk pengembangan profesi kepegawaian untuk memaksimalkan fsilitas yang akan diberikan kepada siswa ataupun siswi dan digunakan dalam berbagai hal dalam proses pembelajaran yang akan berlangsung. Pembiayaan dalam satuan pendidikan bukan hanya ditanggung oleh masyarakat sebagai wali murid melainkan juga pemerintah pusat dan daerah juga memiliki andil dalam pembiayaan pendidikan, karena pada prinsipnya negara memberikan jaminan kepada masyarakatnya mengenai jaminan pendidikan bagi masyarakat secara merata. Hal itu sebagaimana yang dijelaskan pada Undang-Undang Republik Indonesia tentang Sistem Pendidikan Nasional, sebagai berikut:

1. Pembukaan Undang-Undang Dasar 1945 yang menjelaskan bahwa "mencerdaskan kehidupan bangsa"

2. Pasal 31 ayat 2 UUD 1945 "Setiap warga negara wajib mengikuti pendidikan dasar, dan pemerintah wajib mebiayainya"

ayat 4 yang menjelaskan tentang "negara memprioritaskan anggaran pendidikan sekurang-kurangnya $20 \%$ dari APBN dan APBD untuk memenuhi penyelenggaraan pendidikan nasional"

3. Pasal 49 ayat 1 UU No. 20 tahun 2003 menyatakan "alokasi dana pendidikan minimal 20\% dari APBN, dan 20\% dari APBD selain gaji dan biaya. pendidikan kedinasan"

4. Pasal 34 ayat 1-2 UU No. 20 tahun 2003 menyatakan "setiap warga negara yang berusia 6 (enam) tahun dapat mengikuti program wajib belajar dari Pemerintah Pusat dan Pemerintah Daerah serta menjamin terselenggaranya wajib belajar minimal pada jenjang pendidikan dasar tanpa memungut biaya"

Undang-Undang No.20 Tahun 2003 tentang Sistem Pendidikan Nasional (Sisdiknas) dalam satu bab tersendiri, yaitu "Bab XIII (Pendanaan Pendidikan) dengan empat pasal (pasal 46, 47, 48 dan 49)" . Bab XIII merupakan BAB yang mengatur mengenai "tanggung jawab pendanaan (pasal 46), sumber pendanaan (47), pengelolaan dana pendidikan (pasala

${ }^{68}$ Undang-Undang Republik Indonesia tentang Sistem Pendidikan Nasional. 
48), dan pengalokasian dana pendidikan (pasal 49)." Secara rinci diatur dalam pasal pasal sebagai berikut Pasal 46 tentang tanggung jawab pendanaan:

1. Tanggungjawab pendanaan satuan pendidikan menjadi tanggungjawab pemerintah pusat, pemerintah daerah serta masyarakat sebagai wali dari peserta didik .

2. Pemerintah pusat dan pemerintah daerah harus bertanggungjawab dalam penyediaan dana pendidikan sebagaimana yang telah diatur dalam pasal 31 ayat 4 Undang-Undang Dasar Negara Republik Indonesia tahun 1945 .

3. "Tanggungjawab dalam pendanaan pendidikan diatur lebih lanjut dengan peraturan pemerintah" dalam ayat 1 dan ayat 2 .

Undang-Undang Nomor 20 tahun 2003 mengenai sistem pendidikan nasional menjelaskan tentang pendanaan satuan pendidikan, berikut ini penjabaran tentang peraturan perundang-undangan nomor 20 tahun 2003:

1. Pasal 46 mengenai "Tanggungjawab Pendanaan"

a. Pendanaan pendidikan menjadi tanggung jawab bersama antara Pemerintah, Pemerintah Daerah, dan masyarakat

b. Pemerintah dan Pemerintah Daerah bertanggung jawab menyediakan anggaran pendidikan sebagaimana diatur dalam Pasal 31 ayat (4) Undang-Undang Dasar Negara Republik Indonesia Tahun 1945

c. Ketentuan mengenai tanggung jawab pendanaan pendidikan sebagaimana dimaksud dalam ayat (1) dan ayat (2) diatur lebih lanjut dengan Peraturan Pemerintah

2. Pasal 47 mengenai "Sumber Pendanaan Pendidikan"

a. Sumber pendanaan pendidikan ditentukan berdasarkan prinsip keadilan, kecukupan, dan keberlanjutan

b. Pemerintah, Pemerintah Daerah, dan masyarakat mengerahkan sumber daya yang ada sesuai dengan peraturan perundang-undangan yang berlaku

c. Ketentuan mengenai sumber pendanaan pendidikan sebagaimana dimaksud dalam ayat (1) dan ayat (2) diatur lebih lanjut dengan Peraturan Pemerintah

3. Pasal 48 mengenai "Pengelolaan Dana Pendidikan"

a. Pengelolaan dana pendidikan berdasarkan pada prinsip keadilan, efisiensi, transparansi, dan akuntabilitas publik

b. Ketentuan mengenai pengelolaan dana pendidikan sebagaimana dimaksud dalam ayat (1) diatur lebih lanjut dengan Peraturan Pemerintah

4. Pasal 49 mengenai "Pengalokasian Dana Pendidikan"

a. Dana pendidikan selain gaji pendidik dan biaya pendidikan kedinasan dialokasikan minimal 20\% dari Anggaran Pendapatan dan Belanja Negara (APBN) pada sektor pendidikan dan minimal 20\% dari Anggaran Pendapatan dan Belanja Daerah (APBD)

b. Gaji guru dan dosen yang diangkat oleh Pemerintah dialokasikan dalam Anggaran Pendapatan dan Belanja Negara (APBN) 
c. Dana pendidikan dari Pemerintah dan Pemerintah Daerah untuk satuan pendidikan diberikan dalam bentuk hibah sesuai dengan peraturan perundang-undangan yang berlaku

d. Dana pendidikan dari Pemerintah kepada Pemerintah Daerah diberikan dalam bentuk hibah sesuai dengan peraturan perundang-undangan yang berlaku

e. Ketentuan mengenai pengalokasian dana pendidikan sebagaimana dimaksud dalam ayat (1), ayat (2), ayat (3), dan ayat (4) diatur lebih lanjut dengan Peraturan Pemerintah.

\section{B. Tanggung Jawab Dalam Pendanaan Pendidikan}

"Peraturan setiap sekolah mengharuskan pengelolaan dana disusun sesuai dengan standart pembiayaan" sesuai dengan Peraturan Menteri Pendidikan Nasional Nomor 19 Tahun 2007. Pedoman peraturan diatur sesuai dengan:

1. Sumber pemasukan dana, pengeluaran dana serta dana yang dikelola

2. Penggalangan dana, penyusunan serta pencairan dana

3. Pembelanjaan yang sesuai dengan proses pembelajaran merupakan tanggungjawab dan wewenang kepala sekolah

4. Pemasukan dan pengeluaran dilaporkan dalam bentuk proposal, serta penggunaan anggaran dalam proses pembelajaran dilaporkan kepada komite dan yang memiliki wewenang diatas kepala sekolah atau institusi

Penetapan anggaran belanja dalam proses pembelajaran ditetapkan kepala sekolah yang nantinya akan disetujui oleh yayasan atau institusi diatasnya. Setelah persetujuan dari atasan, penetapan pedoman tersebut disosialisasikan kepada warga sekolah untuk transparan terhadap pemasukan dan pengeluaran anggaran.

Pemerintah pusat, pemerintah daerah serta masyarakat ikut andil bertanggungjawab dalam pembiayaan pendidikan. Oleh karena itu, secara nasional pendidikan bukan hanya tanggungjawab masyarakat sendiri melainkan juga pemerintah yang mengatur pembiayaan serta bertanggungjawab dalam menyediakan pendidikan bagi masyarakat.

Kebutuhan pribadi peserta didik berupa pengeluaran untuk transportasi, seragam, buku pegangan atau tambahan, uang saku, pembelajaran tabahan atau yang lainnya merupakan tanggungjawab dari wali murid atau orangtua wali dari siswa atau siswi. Bukan hanya itu, selain untuk kebutuhan peserta didik secara pribadi, orangtua wali juga ikut andil dalam tanggungjawab anak dalam pembiayaan didalam menutupi kekurangan pembiayaan sekolah bisa berupa SPP atau sumbangan lain yang telah diatur serta disetujui oleh kepala sekolah. Berikut ini jenis pembiayaan satuan pendidikan yang dibebankan kepada wali murid menurut Matin, yaitu: ${ }^{69}$

1. Sumbangan Pembinaan Pendidikan (SPP)

\footnotetext{
${ }^{69}$ Susiana, Tesis Pola Pengelolaan Pembiayaan Madrasah Ibtidaiyah Swasta MIS AlJihad Medan Sunggal, (Medan: Pascasarjana Universitas Negeri Medan, 2016).
} 
Yayasan atau satuan pendidikan menentukan besaran anggaran SPP yang harus dibayarkan wali murid. Spp sifatnya adalah wajib bagi wali murid untuk membiayainya, karena ketetapan dari sekolah untuk kelangsungan proses pembelajaran.

2. Sumbangan Badan Pembantu Penyelenggara Pendidikan (SBP3)

Sumbangan lain-lain dimaksudnya pada sumbangan diluar anggaran sekolah. Harapannya melalui sumbangan dari BP3 atau Badan Pembantu Peyelenggara Pendidikan serta PMOG atau Persatuan Orangtua Murid dan Guru dapat membantu penyelenggaraan pendidikan pada satuan pendidikan atau sekolah.

3. Sumbangan lain-lain

Dana yang dikeluarkan oleh wali murid selain yang dijelaskan pada poin satu dan dua, terdapat pembiayaan lain yang sifatnya incidental, untuk pembiayaan kegiatan ekstra kulikuler sesuai yang diikuti siswa atau siswi, alat-alat laborat, pembangunan gedung, dana praktek, atau yang lainnya sesuai dengan aturan yang telah disetujui oleh kepala sekolah beserta yayasan satuan pendidikan atau sekolah.

Semua pendanaan yang masuk ke satuan pendidikan atau sekolah sebaiknya dikelola dan dilaporkan secara berkala agar transparan dan akuntabel. Oleh Karena pihak lain yang memiliki perhatian atas pembiayaan pendidikan juga memiliki hak untuk mengetahui dana yang dikeluarkan untuk sekolah akan dialokasikan untuk apa.

Beberapa sumbangan sukarela biasanya ada pada satuan pendidikan atau sekolah yang diselenggarakan oleh swasta atau yayasan. Sumber dana tersebut dibagi menjadi dua bagian berupa dana pinjaman (loan) dan dana hibah (grant). Sumbangan bisa berasal dari dalam atau luar negeri yang mempunyai perhatian khusus pada dunia pendidikan serta kebudayaan. Sumbangan yang diberikan akan dialokasikan untuk mewujudkan program yang telah dicanangkan sekolah, selain itu untuk memajukan pendidikan sekolah yang memiliki tujuan melancarkan pelaksanaan dalam proses pendidikan kedepannya. ${ }^{70}$

Dana dari pemerintah berupa dana BOS yang ditanggung oleh pemerinntah pusat, dari pemerintah propinsi juga memiliki tanggungngan untuk dana BOS, selain itu dari kabupaten atau propinsi ada BOS pendamping. Namun dana BOS yang dikeluarkan oleh pemerintah dialokasikan untuk Sekolah Dasar (SD) dan Sekolah Menengah Pertama (SMP). Khusus untuk dana Sekolah Menengah Atas (SMA) dan SLTA dana operasional yang masuk untuk peserta didik dari dana BOS pemerintah propinsi, karena tidak adanya alokasi secara khusus dari pemerintah pusat dann daerah. Namun, pemerintah pusat, pemerintah propinsi serta pemerintah daerah memiliki andil dalam dana yang diberikan sekolah untuk biaya investasi.

Adanya program wajib belajar dua belas tahun yang diupacayakan melalui program PIP atau Program Indonesia Pintar, baik itu formal maupun nonformal yang diprakarsai dan dilaksanakan dibawah pengawasan pemerintah pusat atau pemerintah daerah. Hal itu nantinya menjadi tanggungjawab pemerintah sebagai pelaksana. Anggaran dana yang akan

\footnotetext{
${ }^{70}$ Ibid. hlm: 31.
} 
didapat dari pemerintah pusat serta pemerintah daerah untuk anggaran tambahan investasi tanah yang digunakan untuk pengembangan satuan pendidikan atau sekolah menjadi taraf yang lebih atas atau internsional yang memiliki basis keunggulan lokal. Anggaran tersebut berarti bersumber dari: pemerintah pusat, pemerintah daerah, dan masyarakat.

Biaya personal adalah biaya pendidikan yang harus dikeluarkan oleh orangtua wali selaku orangtua dari peserta didik. Biaya digunakan untuk proses pembelajaran yang akan berlangsung dan sifatnya berkelanjutan. Beban yang diberikan kepada wali murid digunakan untuk keperluan pribadi siswa untuk dapat mengikuti proses pembelajaran. Anggaran yang harus dikeluarkan wali murid berupa: Sepatu, Seragam sekolah, Seragam Olahraga, Perlengkapan alat tulis, Uang saku, Uang transportasi, Dana ekstrakulikuler.

\section{Sumber Pendanaan Pendidikan}

"Sumber Pendanaan Pendidikan telah diatur dalam Undang-Undang Nomor 20 Tahun 2003 Pasal 47"71, yaitu:

1. Sumber pendanaan pendidikan ditentukan berdasarkan prinsip keadilan, kecukupan, dan keberlanjutan

2. Pemerintah, pemerintah daerah, dan masyarakat mengerahkan sumber daya yang ada sesuai dengan peraturan perundang-undangan yang berlaku

3. Ketentuan mengenai sumber pendanaan pendidikan sebagaimana dimaksud dalam ayat (1) dan (2) diatur lebih lanjut dengan peraturan pemerintah

Pemerintah pusat maupun pemerintah daerah memiliki andil dan tanggungjawab dalam pendanaan pendidikan bukan hanya memberikan anggaran semata melainkan juga mengatur dan mengawasi anggaran dana yang dikeluarkan sesuai dengan Undang-Undang Nomor 20 Tahun 2003 Pasal 47.

Kategori utama dalam sumber pendanaan pendidikan yang masuk pada dana sekolah berupa dana atau anggaran dari pemerintah, wali murid, serta kelompok masyarakat yang memiliki perhatian khusus pada dunia pendidikan. Berikut ini penjelasannya: ${ }^{72}$

1. Pemerintah

Anggaran dari pemerintah terdapat dua kategori yaitu pemerintah pusat dan pemerintah daerah. Keuangan sekolah dibantu pemerintah pusat yang mencakup beberapa hal, sebagai berikut :

a. Dana hibah atau Grant berupa dana BOS atau Biaya Operasional Sekolah

b. Pembayaran gaji guru

c. Membantu mengadakan proyek utuk Anggaran pengembangan gedung termasuk rehabilitasi bangunan gedung sekolah, penyediaan bantuan teknis berupa bahan dan perlengkapan

\footnotetext{
${ }^{71}$ Indra Bastian, Akuntansi Pendidikan, (Jakarta: Erlangga, 2007), h. 163.

72 http://asrivixel.blogspot.com/2009/02/buku-pembiayaan-pendidikan.html
} 
d. Melakukan kontribusi secara tidak langsung pada kegiatan pelatihan kepala sekolah dan guru dalam mengembangkan profesi dan menjadikan pendidikan yang profesional dan menarik.

Selain pemerintah pusat, pemerintah daerah juga ikut andil dalam tanggungjawab pendanaan pendidikan. Selain pemerintah pusat, pemerintah daerah juga memiliki tanggungjawab dalam menggaji guru, pengadaan sarana dan prasarana yang memadai, pemngembangan bangunan sekolah, fasilitas yang diperlukan, dengan anggaran berasal dari APBD dan APBN. Bagi daerah yang memiliki pendapatan yang tinggi berpeluang lebih besar dalam membantu pemenuhan kebutuhan anggaran dalam menyelenggaraan sekolah.

2. Wali murid

Pendanaan bagi wali murid sebagai kewajiban karena pemerintah belum mampu dalam memenuhi kebutuhan seluruh perlengkapan dan lain-lain di sekolah. Kontribusi yang diberikan wali murid kepada sekolah bermacammacam sesuai dengan kebutuhan sekolah. Berikut ini anggaran yang dibebankan kepada wali murid:

a. Anggaran pendidikan yang telah ditentukan dari sekolah

b. Berkontribusi pada komite sekolah

c. Anggaran untuk membangun fasilitas sekolah

d. Menyumbangkan keahlian, kemampuan atau keterampilannya dalam berbagai kegiatan yang ada di sekolah

e. Anggaran tambahan untuk guru yang memberikan pembelajaran tambahan diluar pembelajaran sekolah

f. Anggaran buku yang dibutuhkan atau perlengkapan lain

g. Anggaran untuk kesejahteraan anak saat di sekolah berupa uang jajan atau uang transportasi

3. Peserta didik

Anggaran dana juga bisa didapatkan dari peserta didik melalui penggalangan dana atau memanfaatkan dirinya sendiri dalam menggali kemampuan diri. Keterlibatan peserta didik dalam mendapatkan anggaran bagi sekolah dapat melalui praktik dalam bidang pertanian, perternakan, pembuatan kerajinan atau yang lainnya. Nantinya hasil dari pertanian, perternakan serta kerajinan tangan bisa dijual dan bisa menjadi pemasukan bagi sekolah. Selain itu, melalui turnamen, mengikuti bazar, dan mengadakan pertunjukkan dikhalayak umum juga bisa menjadi salah satu pemasukan sekolah dari peserta didik. 
4. Yayasan

Satuan pendidikan tidak hanya didirikan oleh pemerintah melainkan juga bisa didirikan pihak swasta yang telah mendapatkan persetujuan dari pemerintah. Sekolah swasta juga masih dibawah naungan pemerintah. Setiap sekolah memiliki tujuan yang sama yaitu menghasilkan lulusan yang cerdas dan beradab. Sekolah swasta mendapatkan dana untuk pembangunan berupa tanah, bangunan, perlengkapan serta sumber daya manusia dari yayasan.

\section{Sumber Pendanaan Pendidikan Islam Pada Masa Klasik}

Pada masa klasik dunia islam, pembiayaan pendidikan di tanggung bersama oleh beberapa pihak, pihak-pihak tersebut saling membantu untuk mewujudkan tujuan pendidikan islam dengan memberikan sokongan dana khusus yang di alokasikan untuk pendidikan, sumber-sumber pendanaan dalam islam pada masa klasik di antaranya adalah berasal dari :

1. Subsidi Negara

Sejak masa Khulafaur Rasyidin, para penguasa dan pemimpin muslim memiliki perhatian yang sangat besar terhadap ilmu pengetahuan. Mereka mendirikan dan menghidupi berbagai sarana penunjang ilmu pengetahuan dan pendidikan, termasuk lembaga-lembaganya. As-Suffah (salah satu ruangan masjid yang digunakan untuk mengajar para sahabat sekaligus sebagaipondokan bagi mereka yang sangat miskin) yang menjadi salah satu model pendidikan Islam di Madinah, tersebar luas ke luar Madinah sejalan dengan penyebaran Masjid. Keberlangsungan As-Suffah ini sangat diperhatikan oleh Khulafaur Rasyidin. Umar bin Khattab senantiasa mengangkat para sahabat rasul yang memiliki pengetahuan agama yang luas sebagai gubernur dan panglima. Mereka banyak mendirikan masjid dengan As-Suffah di dalamnya, kegiatan pendidikan yang berlangsung di dalamnya dibantu pembiayaannya dengan dana pemerintah yang tersedia Pada masa Umayyah di daerah-daerah baru, dimana bahasa Arab bukan merupakan bahasa pertama dan Al-Qur'an belum dikenal, pembangunan lembaga-lembaga pendidikan seperti kuttab dan masjid menjadi tujuan utama para khalifah dan gubernur setempat. Dimana pendanaan lembaga-lembaga tersebut sangat tergantung dengan pemerintah sebagai pemerakarsa. ${ }^{73}$

Selanjutnya pada masa Abbasiyah, banyak bermunculan Masjid Jami' (masjid dengan bangunan besar yang dihiasi dengan hiasan-hiasan indah melalui biaya negara) yang berfungsi sebagai tempat diumumkannya berbagai hal tentang negara dan agama

\footnotetext{
${ }^{73}$ Rahmawati Rahim, Pola pembiayaan Pendidikan Islam Pada Masa Kalasik, Ta'dib : 01(2012), 73-74.
} 
pada masyarakat yang di dalamya banyak terdapat halaqah-halaqah yang dipimpin oleh seorang syaikh yang diangkat oleh seorang khalifah untuk mengajarkan bidang kajian tertentu. Dimana biaya keberadaan dan operasionalnya ditanggung sepenuhnya oleh pemerintah. Dimasa Turki Saljuk banyak madrasah- madrasah yang didirikan dan dilembagakan dibawah penguasaan dan bantuan negara. Banyak sekali dana-dana yang dialokasikan untuk mendirikan dan memelihara sekolab-sekolah ini, antara lain dengan memberikan beasiswa yang besar, pensiun dan ransum yang diberikan kepada para mahasiswa yang patut menerimanya. ${ }^{74}$

2. Waqaf

Waqaf pada asalnya mengekalkan yang asal dan memanfa'atkannya untuk kebaikan, yang asal dalam waqaf adalah dengan tujuan mendekatkan dir i kepada Allah SWT. Waqaf merupakan salah satu bentuk ibadah dalam Islam yang berhubungan dengan harta benda. Sebagai salah satu bagian dari sistem pendanaan pendidikan, wakaf menjadi semacam lembaga yang terorganisir dengan baik dan menjadi mode di masa Abbasiyah terutama pada masa keemasan peradaban Islam. Khalifah AlMakmun diauggap sebagai pemerakarsa berdirinya badan-badan waqaf untuk lembaga pendidikan, sehingga pembiayaan beragam kegiatan keilmuan, termasuk gaji para ulama'nya dapat berlangsung terus dan kokoh. Prakarsa Al-Makmun ini kemudian meluas kepada para penggantinya dan para pembesar-pembesar negara, sehingga badan waqaf yang permanen dipandang sebagai suatu keharusan dalam mendirikan suatu lembaga ilmiah. Harta yang dijadikan waqaf ini kebanyakan merupakan aset ekonomi yang berjalan seperti tanah pertanian, rumah, toko, ladang, sawah, pabrik dan sebagainya, dana yang dihasilkan akan bervariasi sesuai dengan kondisi ekonomi pada waktu itu. Oleh karenanya, tingkat kehidupan para pelajar dan pengajar yang dibiayai oleh hasil waqaf berubah-rubah dari waktu ke waktu. Meskipun demikian peranan waqaf sangat membantu pelaksanaan pendidikan. Dengan dana waqaf, umat islam mendapat kemudahan dalam menuntut ilmu, para pelajar dan orang tua mereka tidak terbebani dengan berbagai macam biaya yang diambil untuk kegiatan pendidikan. Di masa Islam klasik Lembaga-lembaga pendidikan yang dihidupi oleh sistem waqaf ini banyak sekali antara lain seperti Badr ibn Hasanawaih Al-Kurdi, seorang bangsawan kaya yang menjadi gubernur, mendirikan 3000 masjid dengan

\footnotetext{
${ }^{74}$ Ibid, HIm. 74.
} 
akademi di dalamnya. Masing-masing masjid memiliki asrama (Masjid Khan). Waqaf Abdul Latif satu dirham diberikannya setiap hari sampai maut memisahkan mereka. Para siswa yang berasal dari keluarga yang tidak mampu atau yang belajar atas inisiatif dan biaya sendiri, umumnya mereka belajar sambil bekerja guna membiayai pendidikannya. ${ }^{75}$

\section{Sumber Lain}

Pandangan bahwa ilmu agama, terutama al- Qur'an harus diajarkan pada orang lain sebagai salah satu bentuk ibadah `ammah mendorong para pengajarnya untuk tidak meminta dan tidak menerima bantuan finansial dari siapapun. Mereka berusaha untuk membiayai kehidupan dan kegiatan pendidikannya hanya dari hasil keringat mereka sendiri diluar kegiatan mengajar. Abu Al-Abbas Al-Ashamm, salah seorang ulama besar dan ahli hadits di Khurasan tidak mau mengambil upah ketika beliau mengajarkan hadits. Beliau memenuhi kebutuhan hidupnya sehari-hari dari hasil usahanya sendiri Banyak sekali cerita-cerita dari literatur Arab yang menjelaskan bahwa para pengajar dan pendidik duduk memberikan materi pelajaran pada masyarakat tanpa mengharapkan bayaran sedikitpun. Salah seorang diantaranya adalah Kamaluddin Abu Al-Barakat Al-Anbary, (seorang ahli Fiqh dan Nahwu), senantiasa membukakan pintu rumahnya bagi para penuntut ilmu, semata-mata karena Allah. Bahkan para guru yang mengajar para kanak-kanakpun tidak menerima bayaran apaapa, seperti Al-Dhahak ibnu Muzahim dan Abdullah ibn Harits, bahkan mereka bersedia membiayai sendiri kegiatan pendidikan tersebut. Disamping para pengajar yang mempunyai keinginan dan kesadaran di atas, banyak para hartawan \& demawan yang mengeluarkan sejumlah dana guna membiayai berbagai lembaga pendidikan dan kegiatannya Antara lain, Al-Hakam II (961 M-976 M) membuka sejumlah kuttab di Kardova. Guru-gurunya digaji dari kantongnya sendiri dan materi pelajaran yang diberikan kepada siswa-siswanya, selain Al- Qur'an, adalah menulis prosa, puisi, grammar dan kaligrafi. ${ }^{76}$

\footnotetext{
${ }^{75} \mathrm{Ibid}, \mathrm{HIm} .75$

${ }^{76}$ Ibid, HIm.75-76
} 


\section{BAB VI \\ PEMBIAYAAN PENDIDIKAN DI ERA OTONOMI DAERAH}

\section{A. Pengertian Dan Tujuan Otonomi Daerah}

Otonomi daerah dalam banyak rujukan di katakan sebagai hak, wewenang dan kewajiban sebuah daerah untuk mengurusi daerahnya sendiri, wewenang tersebut diperoleh daerah dari pemerintah pusat yang telah menyerahkan segala urusan mengenai tata kelola daerah kepada daerahnya masing-masing sesuai dengan kondisi dan kemampuan dari masing-masing daerah, hal ini di sesuaikan dengan perubahan konsep dari sentralistik menjadi desentralistik yang merupakan sebuah konsep dengan isyarat penyerahan kewenangan dari pemerintah di tingkat pusat kepada perintah di tingkat daerah untuk mengurusi dan mengelola wilayahnya sendiri. ${ }^{77}$

Pengertian di atas sesuai dengan undang-undang nomor 22 tahun 1999, dari uraian di atas tampak jelas bahwasannya dengan adanya otonomi ini daerah di beri keleluasaan oleh pemerintah pusat untuk mengatur kepentingannya sendiri, hak dan wewenang yang menjadi tanggung jawab pemerintah daerah meliputi pengelolaan sumberdaya alam dan pengaturan ekonomi daerahnya sendiri, otonomi daerah juga berarti adanya usaha perimbangan tugas peran dan fungsi antara pemerintah pusat dan pemerintah daerah, sehingga daerah di tuntut untuk berinovasi secara intern demi tercapainya kemajuan di daerahnya sendiri. ${ }^{78}$

Kebijakan otonomi daerah di Indonesia secara umum bertujuan untuk memberikan keleluasaan bagi masyarakat di daerah untuk mengembangkan daerahnya masing-masing sesuai potensi yang di milikinya, kebijakan ini bagi masyarakat di desa di harapkan akan memberikan kesempatan bagi pemerintah tingkat daerah untuk berlomba-lomba dalam memajukan masyarakat di daerahnya dengan langkah-langkah strategik sesuai kebutuhan masyarakat di daerahnya. ${ }^{79}$

Dengan adanya kebijakan otonomi daerah ini juga di harapkan bagi setiap daerah agar senantiasa berusaha bergerak untuk maju, bergerak untuk mandiri, sejahtera dan kompeititif dalam melaksanakan program pemerintahan dan program pembangunan daerahnya. ${ }^{80}$ artinya otonomi ini bertujuan untuk lebih meningkatkan efektivitas dan efisiensi fungsi-fungsi lembaga pelayanan masyarakat yang ada di daerah untuk membrikan pelayanan yang terbaik kepada seluruh lapisan masyarakat yang berada di bawah naungannya, karam dengan di berlakukaknnya otonomi ini setiap daerah telah di beri

\footnotetext{
77 Sakinah Nadir, 'Otonomi Daerah Dan Desentralisasi Desa', Jurnal Politik Profetik, 1.1 (2013) <https://doi.org/10.24252/jpp.v1i1.1621>.

78 Sani Safitri, 'Sejarah Perkembangan Otonomi Daerah Di Indonesia', Jurnal Criksetra, 5.9 (2016), $79-83$.

${ }^{79}$ Nadir.

${ }^{80}$ Safitri.
} 
kebebasan seluas-luasanya dalam mengatur rumah tangganya, maka di harapkan setiap daerah akan melakukan tindakan pengembangan daerahnya sesuai dengan kebutuhan, kondisi serta aspirasi masyarakat yang berada di dalam wilayahnya. ${ }^{81}$

Khusus pada bidang pendidikan, otonomi daerah ini bertujuan untuk mengatasi permasalahn pendidikan yang selama ini belum teratasi, salah satu penyebab permasalahan tersebut di sinyalir karena sistem sentralistik yang selama ini berjalan dalam penentuan kebijakan pendidikan di indonesia, maka dengan adanya desentralisasi atau otonomi ini di harapkan permasalahan-permasalahan yang di hadapi pada bidang pendidikan dapat segara di atasi dengan cara memberikan wewenang penyelesain masalah tersebut kepada masingmasing daerah, hal ini karena setiap daerah pasti lebih tahu tentang jenis pendidikan seperti apa yang di butuhkan oleh daerah tersebut, dan cara untuk mengatasi permasalahn yang terjadi di wilayahnya, hal ini bertolak belakang dengan sistem sebelumnya yaitu sentralistik yang memukul rata sebuah kebijakan pemerintah pusat untuk di berlakukan dan di laksanakan oleh seluruh lembaga terkait, padahal kebutuhan setiap daerah pasti berbeda, hal ini menimbulkan permasalahan besar pada dunia pendidikan di Indonesia. ${ }^{82}$

\section{B. Sejarah Otonomi Daerah di Indonesia}

Sejarah otonomi pendidikan tidak dapat dipisahkan dari sejarah perjalanan otonomi daerah itu sendiri karena pendidikan merupakan salah satu bidang dari sekian banyak bidang yang ikut terimbas oleh kebijakan ini, makna otonomi daerah secara sederhananya adalah kemandirian suatu daerah untuk membuat dan mengambil keputusan menganai urusanurusan di dalam daerahnya sendiri. ${ }^{83}$ perjalanan sejarah otonomi daerah di Indonesia telah di mulai sejak lama, bahkan sejak Indonesia belum mendapatkan pengakuan kedaulatannya, sistem desentralisasi diindonesia telah lama di bentuk oleh kolonial Belanda dan Jepang, meskipun sistem desentralisasi pada waktu itu bukanlah untuk kepentingan bangsa Indonesia, akan tetapi lebih karena kepentingan penjajah itu sendiri. ${ }^{84}$

Sejarah otonomi daerah di Indonesia berjalan sejak masa penjajahan hingga pasca reformasi, Pada masa kolonial Belanda, pemerintah India Belanda pernah menerbitkan peratura dasar tentang ketatatanegaraan terkait dengan otonomi daerah, (Buku UU 185 nomor 2) buku ini menjelaskan tentang peraturan administrasi negara Hindia Belanda, dalam buku peraturan ini India Belanda tidak sepenuhnya menerapkan desentralisasi pemerintahan, akan tetapi lebih kepada dekonsentralisasi, yaitu penyerahan berbagai urusan dari pemerintah pusat kepada lembaga-lembaga lain yang berada di bawahnya, baru pada tahun 1903 pemerintah Belanda mengeluarkan keputusan tentang decentralisatiewet yang memungkinkan di bentuknya satuan pemerintahan yang dapat mengelola keuangannya sendiri, pelaksanaan pemerintahan di serahkan kepada dewan-dewan pada masing-masing

\footnotetext{
${ }^{81}$ Nadir.

82 Hartono, 'Otonomi Pendidikan', POTENSIA: Jurnal Kependidikan Islam, 14 (2015), 51-66.

83 Hartono.

${ }^{84}$ Badan Penelitian dan Pengembangan Kementerian Dalam Negeri, 'Menelisik Sejarah Otonomi Daerah', Media BPP Kementerian Dalam Negeri, 2017, 1-60.
} 
daerah, namun dalam pelaksanaannya nyatanya pemerintah daerah tidak punya banyak wewenang untuk mengatur secara penuh urusan di daerahnya, karena pemerintah pusat telah banyak memberikan batasan wewenang dan pengawasan yang sangat ketat terhadap pemerintahan di daerah.

Seiring berjalannya waktu pemerintah India Belanda menerbitkan kembali undangundaang tahun 1922 yang menghasilkan pembagian wilayah kekuasaan dengan sebutan, provinsi, kabupaten, kota, dan kelompok masyarakat, pengaturan tingkatan kepengurusan di bawah pemerintahan pusat ini semata-mata hanya demi kpentingan Belanda agar memudahkan mereka dalam mengatur dan melakukan kontrol terhadap pemerintahan yang ada di bawah mereka. Setelah habis masa Belanda maka sejarah otonomi di Indonesia berlanjut pada masa penjajahan Jepang, pada masa ini wewenang daerah untuk mengatur daerahnya sendiri juga sangat di batasi, hanya saja warisan masa pemerintahan jepang yang paling dapat di rasakan hingga saat ini adalah perincian struktur administrasi masyarakat yang di mulai dari panglima tentara Jepang-pejabat militer-residen-bupati-wedana-kepala desa-kepala dusun-RT/RW-kepala rumah tangga.

Setelah Indonesia mampu terlepas dari cengkeraman penjajah, maka sejarah otonomi daerah diindonesia kembali berlanjut pada masa dua orde asar, yaitu orde lama dan orde baru, pada masa dua orde besar ini terdapat peraturan yang tertulis dari presiden yaitu ketetapan presiden nomor 6 tahun 1959 dan ketetapan presiden tahun 1960 yang berisikan tentang pemerintahan daerah, DPRD Gotong rotong dan sekretariat daerah, selanjutnya pada periode tahun 1965-1969, periode ini merupakan periode pergantian orde lama ke orde baru, pada tahun ini di berlakukan undang-undang nomor 18 tahun 1965 tentang pokok-pokok pemerintahan daerah, dalam undang-undang yan baru ini, secara umum Indonesia hanya mengenal satu jenis daerah otonomi yang dibagi menjadi tiga tingkatan daerah, yaitu Kotaraya, Kotamadya, dan Kotapraja, setelah pemerintahan orde lama berakhir maka beberapa keputusan pemerintahan pada masa orde lamapun banyak di gantikan oleh pemerintahan orde baru termasuk penghapusan undang-undang nomor 18 tahun 1965 dan di gantikan dengan undang-undang on 5 tahun 1974 tentang pokok-pokok pemerintahan daerah, pada masa orde baru inilah lahir istilah dekonsentralisasi yang merupakan bentuk penghalusan terhadap desentralisasi dan sentralisasi dengan jargon konsep "otonomi nyata dan bertanggung jawab" menggantikan jargon sebelumnya yaitu "otonomi yang seluasluasnya" banyak pakar yang menyebutkan bahwa masa orde baru merupakan masa matinya otonomi daerah karena sistem pemerintahan lebih cenderung sentralistik yang saat tergantung pada pemerintah yang paling atas.

Setelah habis masa orde baru dan berganti dengan masa reformasi maka pembaharuan undang-undangpun dilakukan dengan menerbitkan undang-undang tentang pemerintah daerah nomor 22 tahun 1999 dan undang-undang Noor 25 tahun 1999 tentang perimbangan keuangan antara pemerintah pusat dan pemerintah daerah, kebujakan ini di keluarkan pada masa pemerintahan B.J Habibi. Dengan terus berkembangnya pemikiran tentang otonomi daerah ini pada akhirnya terjadilah revisi undang-undang nomor 22 tahun 
1999 yang telah direvisi menjadi undang-undang nomor 32 tahun 2004 tentang pemerintahan daerah yang menandakan di mulainya tatanan baru dalam pemerintahan yang sentralistik menjadi desentralistik, perubahan tersebut di dukung kembali dengan pengesahan undangundang nomor 25 tahun 1999 yang telah direvisi menjadi undang-undang nomor 35 tahun 2004 tentang pengaturan keuangan antar pemerintah pusat dan pemerintah daerah. ${ }^{85}$

Sejarah lahirnya otonomi daerah yang secara nyata di laksanakan di Indonesia sebagaimana penulis gambarklan secara singkat dengan paparan di atas merupakan buah dari kegundahan masyarakat dan bentuk protes masyarakat yang berada pada garis kemiskinan padahal mereka tinggal di daerah yang kaya akan sumberdaya alam, meskipun silih berganti terbit peraturan pemerintah tentang urusan pengelolaan sumberdaya alam di daerah ini, nyatanya pengelolaan kekayaan dan sumberdaya alam di daerah-daerah masih di atur oleh pemerintah pusat, hal ini menjadikan masyarakat merasa di rugikan, karena mereka berharap mendapatkan lebih banyak dampak ekonomi yang membuat kehiduan mereka lebih mapan dan tidak berkutat terus menerus pada garis kemiskinan. ${ }^{86}$

\section{Konsep Baru Pola Pembiayaan Pendidikan di Era Otonomi}

Ketika konsep ekonomi daerah mulai di terapkan dan merata di laksanakan di daerahdaerah di Indonesia, tentunya ada banyak aspek yang akan mengalami perubahan dan bahkan harus mengalami perubahan, karena jika tidak mengikuti arus perubahan yang sedang terjadi maka bisa mati karena tekanan arus perubahan tersebut. Begitu juga dengan pengelolaan keuangan di masa otonomi daerah, tentunya juga mengalami perubahan sebagai proses penyesuaian dengan kondisi yang ada, perlu adanya penataan kembali keuangan pusat dan daerah, antara pendapatan dan pengeluaran, penataan ini sangatlah penting karena akan bersinggungan langsung dengan kemampuan daerah untuk melakukan pembangunan daerahnya sendiri serta memberikan pelayanan yang terbaik bagi masyarakatnya, kondisi ini juga sangat berpengaruh pada pola pembiayaan pendidikan di era otonomi daerah, bagaimana daerah dapat mengelola keuangan daerahnya demi memaksimalkan proses pendidikan di daerahnya, dan bagaimana pemerintah dapat menjamin pemerataan pelayanan pendidikan yang baik ini menyentuh seluruh lapisan masyarakat, terutama bagi mereka yang tinggal di daerah yang masih dalam kategori miskin. ${ }^{87}$

Lewat undang-undang, pemerintah telah mngeluarkan aturan berkenaan dengan pembiayaan pendidikan, yaitu undang-undanag tentang sistem pedidikan nasional nomor 20 tahun 2003, bab ke XIII Pasal 46-49, di mana di dalamnya di nyatakan tentang tanggung jawab pendanaan pendidikan, sumber pendanaan pendidikan, pengelolaan dana pedidikan, dan pengalokasian dana pendidikan, di dalamnya juga dinyatakan bahwa pembiayaan pendidikan merupakan bagian dari tanggung jawab bersama antara pemerintah pusat dan pemerintah daerah, serta masyarakat, dalam aturan ini jelas peran masyarakat tidak dapat di

\footnotetext{
${ }^{85}$ Negeri.

${ }^{86}$ Safitri.

87 Winarsih.
} 
kesampingkan, masyarakat harus memberikan dukungan penuh terhadap pembiayaan pendidikan di daerah sekitar mereka, dan masyarakat juga harus di bedakan dengan keluarga/orang tua peserta didik, partisipasi masyarakat dalam hal ini dapat di lembagakan dalam bentuk dewan pendidikan daerah dan komite sekolah pada setiap lembaga pendidikan yang ada. ${ }^{88}$

Menurut peraturan pemerintah nomor 38 tahun 2007 yang membahas tentang pembagian wewenang pemerintahan antara pemerintah pusat, pemerintah tingkat provinsi, dan pemerintah tingkat daerah, dalam peraturan ini di nyatakan tentang pembagian tanggung jawab pengelolaan pendidikan yang menjadi tanggung jawab pemerintah daerah kabupaten dan kota, wewenang-wewenang tersebut diantaranya adalah : pertama, wewenang untuk menetapkan kebijakan operasional dan perencanaan operasional pendidikan. Kedua, penyelanggaraan dan pengelolaan pendidikan pada pendidikan dasar dan menengah yang berbasis keunggulan lokal. Ketiga, pengawasan atas pelaksanaan kurikulum tingkat satuan pendidikan pada tingkat dasar, pembinaan tenaga pendidik dan tenaga kependidikan bagi lembaga pendidikan tingkat PAUD, Pendidikan dasar, pendidikan menengah dan pendidikan nonfromal. Keempat, wewenang untuk melaksanakan koordinasi, pemberian fasilitas, Monitoring, dan evaluasi pelaksanaan ujian sekolah skala kabupaten/kota, wewenang di atas di limpahkan kepada dinas pendidikan di masing-masing daerah. ${ }^{89}$

Melihat beberapa paparan di atas, maka kita perlu melakukan kajian lebih mendetail lagi tentang seperti apakah pola pembiayaan pendidikan di era otonomi daerah dengan segala aspek yang mengikutinya, namun perlu kita ketahui pula, dari mana sumber dana pendidikan dari tingkat nasional hingga tingkat sekolah, ditingkat nasional sumber pembiayaan pendidikan setidaknya berasal dari berbagai sumber, di antaranya adalah : 1) pendapatan negara dari hasil pajak yang sangat beragam jenisnya, 2) pendapatan negara dari sektor non pajak yang meliputi hasil pengolahan sumber daya alam dan hasil dari produksi nasional ( $g a s$ dan non-migas), 3) hasil keuntungan dari eksporbarang dan jasa, 4) badan usaha milik negara (BUMN), 5) bantuan dalam bentuk pemberian atau hibah, dan bantuan luar negeri, baik dari lembaga keuangan nasional maupun internasional. pengalokasian dana tingkat nasional ini di susun dan di rencanakan setiap tahunnya yang biasa di sebut dengan Rencana Anggaran Pendapatan dan Belanja Negara (RAPBN). Sumber dana pendidikan untuk tingkat provinsi, kabupaten dan kota, berasal dari pemerintah pusat dan di tambah dengan sumber dana dari Pendapatan Asli Daerah (PAD), perencanaan penganggaran pada tingkat ini biasa disebut dengan Rencana Anggaran dan Pendapatan Belanja Daerah (RAPAD). Sedangkan pada tingkat sekolah, biaya pendidikan di dapatkan dari bantuan pemerintah pusat, pemerintah daerah, iuran siswa, dan bantuan dari masyarakat, sebagaian besar anggaran pendidian di tingkat sekolah di dapat dari pemerintah pusat bagi sekolah negeri, dan bagi sekolah swasta biaya pendidikan di dapat dari iuran siswa dan bantuan dari yayasan, program perencanaan

\footnotetext{
88 Syakdiah, 'Pendanaan Pendidikan Di Indonesia', Jurnal Kebijakan Dan Administrasi Publik, 2005, $109-22$.

${ }^{89}$ Novendra Hidayat, 'Otonomi Daerah Dan Desentralisasi Pendidikan', Society, VI.35 (2016), 35-49

<http://data4.blog.de/media/285/1849285_62da7ea644_d.pdf>.
} 
anggaran di tingkat sekolah ini biasa di sebut dengan, Rencana Anggaran Pendapatan dan Belanja Sekolah (RAPBS)..$^{90}$

Di era otonomi daerah konsep pembiayaan pendidikan di daerah-daerah yang tersusun dalam RAPAD sesungguhnya sebagian besar anggarannya masih di peroleh dari pusat (Block Grant) yang di salurkan ke setiap daerah dalam bentuk paket Dana alokasi Umum dan Dana Alokasi Khusus (DAU) dan (DAK), hal ini sesungguhnya tidak jauh berbeda dengan pengalokasian anggaran pendidikan di era sentralisasi, di mana anggaran pendidikan pada tingkat kabupaten dan provinsi di peroleh dari pemerintah pusat, tugas pemerintah daerah hanya menyalurkan anggaran tersebut sesuai dengan peraturan yang berlaku, hanya sedikit sekali dana pendidikan yang murni berasal dari anggaran daerah, yaitu hanya sekitar $1 \%$ saja, perbedaan yang mendasar dari era otonomi dan era sentralisasi dalam masalah pembiayaan pendidikan ini terletak pada wewenang dalam pengalokasian dana pendidikan, di era otonomi pengalokasian dana pendidikan keselurahannya menjadi kewajiban pemerintah daerah, namun ada pengkhususan bagi daerah-daerah dengan yang memiliki sumber daya alam yang dikuasai oleh negara, daerah-daerah yang kaya akan sumber daya alam seperti Aceh, Irian jaya, Riau dan Kalimantan timur, akan mendapatkan bagian dengan porsi tertentu dari keuntungan hasil pengolahan sumber daya tersebut, pengalokasian anggaran tambahan ini dari pemerintah pusat di berikan kepada pemerintah provinsi untuk selanjutnya di salurkan kepada pemerintah daerah tingkat kabupaten dan kota dengan menggunakan aturan tertentu, hal ini menjadikan daerah-daerah tersebut tidak hanya mengandalkan anggaran pendidikan dari PAD dan DAU, akan tetapi mereka akan mendapatkan suntikan dana yang lebih besar dari sistem bagi hasil pengelolaan sumberdaya alam di daerah mereka. ${ }^{91}$

Sumber anggaran dan pengalokasian anggaran sebagaimana di jelaskan di atas telah termaktub dalam undang-undang No.25 tahun 1999 yang membahas tentang perimbangan keuangan antara pemerintah pusat dan pemerintahdaerah, di dalamnya di nyatakan selain Dana Alokasi Umum, pemerintah daerah juga berhak menerima dana bagi hasil sumber daya alam, dan Dana Alokasi Khusus, sumber penerimaan daerah yang lainnya adalah dari Pendapatan Asli Daerah, pinjaman daerah dan lain-lain. Selaindana perimbangan, pengalokasian dana bantuan dari pusat ke daerah juga menggunakan mekanisme Dekonsentrasi (pelimpahan wewenang pemerintah pusat kepada gubernur sebagai wakil dari pemerintah pusat), dan tugas pembantuan (pemberian tugas-tugastertentu oleh perintah pusat kepada daerah atau desa yang di dukung dengan bantuan pembiayaan dan di pertanggung jawabkan dam bentuk laporan), khusus pada sektor pendidikan, penyerahan tanggung jawab dan pembiayaan yang terkait dengan dekonsentrasi di serahkan oleh departemen pendidikan nasional kepada gubernur untuk kemudian di teruskan pelaksanaannya kepada dinas

\footnotetext{
${ }^{90}$ Mohammad Zainuddin, Reformasi Pendidikan Di Era Otonomi Daerah, Kementerian Riset Tekknologi Dan Pendidikan Universitas Negeri Malang, I (malang: kementerian riset, teknologi, dan pendidikan tinggi Universitas Negeri Malang, 2015).

91 Zainuddin.
} 
pendidkan di tingkat provinsi, sedangkan penyerahan wewenang dan anggaran tugas pembantuan di serahkan oleh departemen pendidikan nasional kepada Dinas pendidkan di tingkat provinsi, atau kepada dinas pendidkan pada tingkat kabupaten, atau bahkan bisa langsung di serahkan kepada dinas penddidikan tingkat desa. ${ }^{92}$

Setelah Pemberlakuan otonomi daerah, maka seluruh pengelolaan sekolah termasuk pengelolaan pembiayaan pendidikan di setiap sekolah mulai jenjang SD Hingga SLTA menjadi tanggung jawab pemerintah daerah yang di wakilkan kepada dinas pendidikan daerah, kantor wilayah dan departemen pendidikan nasional tidak dapat lagi ikut mengurusi wewenang ini. Bahkan antara dinas pendidikan provinsi dan dinas pendidikankabupaten atau kota sudah tidak ada hubungan secara hierarkis. ${ }^{93}$

Di samping beberapa hal yang telah di jelaskan di atas, termasuk dari konsep desentralisasi pendidikan yang telah di jalankan oleh departemen pendidikan nasional adalah pemberian wewenang seluas-luasnya kepada setiap lembaga, institusi, garau sekolah dengan konsep Manajemen Berbasis Sekolah (MBS), pemberdayaan lembaga pendidikan dengan konsep MBS ini memiliki empat aspek yang menjadi orientasinya, yaitu : peningkatan mutu pendidikan, pemerataan, relevansi, dan efisiensi penyelenggaraan pendidikan. dengan adanya MBS ini juga merubah konsep pembiayaan pendidikan yang semakin tersentralisir kepada sekolah, di mana anggaran yang di berikan daripemerintah pusat pada akhirnya akan di serahkan oleh pemerintah daerah kepada masing-masing sekolah untuk mereka kelola berdasarkan kebutuhan pengembangan dari masing-masing lembaga dan akan di pertangug jawabkan kepada pemerintah daerah dalam bentuk laporan penggunaak keuangan. ${ }^{94}$

Di era otonomi daerah ini, pemerintah daerah memiliki tanggung jawab spenuhnya dalam pengelolaan anggaran pendidikan, sehingga besaran anggaran yang di alokasikan untuk pendidikan tergantung dari seberapa besar perhatian daerah terhadap kemajuan pendidikan di daerahnya masing-masing, dengan adanya peraturan ini sesungguhnya setiap daerah memiliki kesempatan yang sangat besar dam upaya untuk memajukan sektor pendidikan di daerahnya demi peningkatan sumber daya manusia yang ada di daerah mereka, pembangunan pendidikan yang selama ini terlihat kurang efektif ketika di dominasi oleh pemerintah pusat, dapat di antisipasi dengan adanya kebidanan baru ini, maka hendaknya setiap daerah mampu merumuskan konsep reformasi sistem pngelolaan pendidikan termasuk penelolaan pembiayaan pendidikan didaerah dan lebih khusus di sekolah-sekolah, hal ini menjadi sebuah keharusan dalam upaya untuk memajukan pendidikan di Indonesia. ${ }^{95}$

\footnotetext{
92 Nina Toyamah and Syaikhu Usman, 'Alokasi Anggaran Pendidikan Di Era Otonomi Daerah: Implikasinya Terhadap Pengelolaan Pelayanan Pendidikan Dasar', Lembaga Penelitian SMERU, 2004, 1-68 <http://www.smeru.or.id/id/content/alokasi-anggaran-pendidikan-di-era-otonomi-daerah-implikasinyaterhadap-pengelolaan>.

93 Roni Eka Putra and Tengku Rika Valentina, 'Pembiayaan Pendidikan Di Era Otonomi Daerah', Jurnal Demokrasi, IX (2010), 71-92.

${ }^{94}$ Suwandi, 'Arah Kebijakan Pemanfaatan Dan Penyaluran Dana Pendidikan Pada Era Otonomi Daerah', Jurnal Pendidikan Teknologi Dan Kejuruan, 21.2 (2012), 167-78.

${ }^{95}$ Suwandi.
} 


\section{Problematika Pembiayaan Pendidikan di Era Otonomi}

Sejak di maksimalkan pelaksanaan otonomi daerah pada masa revolusi atau setelah berakhirnya orde baru hingga saat ini, tentunya masih banyak kekurangan dan kendala yang di hadapi dari pelaksanaan otonomi tersebut, terutama permasalahan yang menyangkut pembiayaan pendidikan di era otonomi tentunya juga masih banyak masalah-masalah yang mesti di selesaikan, permasalahan tersebut sejatunya juga tidak terlepas dari permasalahan dalam pelaksanaan otonomi daerah itu sendiri, beberapa kendala dalam pelaksanaan otonomi daerah dapat di jabarkan sebagaimana berikut :

1) Kendala Regulasi, belum sempurnanya regulasi yang mengatur pelaksanaan otonomi daerah ini menyebabkan banyak terjadinya konflik kepentingan baik di pusat ataupun di pemerintah daerah.

2) Kendala Koordinasi, Koordinasi yang kurang baik terjalin antara instansi-instansi di pemerintahan pusat melahirkan inkonsistensi peraturan yang membingungkan pihakpihak di pemerintah daerah.

3) Kendala Persepsi, perbedaan persepsi menyebaban perbedaan pendapat yang terjadi di tingkat pusat hingga tingkat daerah yang mengakibatkan pula pada perbedaan dalam pendistribusian kewenangan.

4) Kendala Waktu, setelah runtunya orde baru, semangat untuk mamaksimalkan otonomi daerah ini begitu besar, sehingga menuntut pemerintah untuk merumsukan dan menetukan peraturanperaturan yang menyertai otonomi daerah ini dalam waktu yang relatif singkat dan terburu-buru.

5) Keterbatasan SDM, kurangnya kualitas Sumberdaya manusia di tingkat pusat sebagai pembuat kebijakan hingga tingkat lokal sebagai pelaksanan kebiajakan menjadikan efektivitas pelaksanaan otonomi daerah ini kurang maksimal.

6) Kendala Finansial, keterbatasan ketersediaan anggaran di tingkat pusat dan tingkat daerah ini menjadi masalah yang paling dominan terlihat dalam perjalanan otonomi daerah di Indonesia hingga saat ini. ${ }^{96}$

sedangkan berapa permasalahan yang berkaitan dengan pembiayaan pendidikan di era otonomi daerah adalah sebagai berikut :

1) Sistem anggaran pendidikan di Indonesia masih tergolong kompleks, rumit, birokratis, kaku, dan masih terlalu banyak melibatkan instansi dengan kepentingan masing-masing, memang dengan adanya otonomi daerah yang salah satu tujuannya adalah pemangkasan jalur birokrasi dan penyederhanaan sistem penganggaran pendidikan, namun dalam aplikasinya nyatanya masih banyak permasalahan yang terjadi, dengan pencairan anggaran lewat beberapa instansi DAU, DAK, proyek-proyek pemerintah berskala nasional, regional dan lokal nyatanya mengakibatkan banyak terjadi pengahmburan dan kebocoran anggaran serta penggunaan yang tidak efisien. ${ }^{97}$

\footnotetext{
96 Suprapti.

97 Zainuddin.
} 
2) Perbedaan kondisi di masing-masing daerah yang menyebabkan perbedaan pula pada kemampuan masing-masing daerah dalam pengelolaan pembiayaan pendidikan di daerahnya, daerah-daerah yang kaya akan sumber daya alamnya secara otomatis akan mendapatkan suntikan anggaran pendidikan yang cukup banyak, tapi sebaliknya bagi daerah-daerah terpencil dan tidak memiliki sumber daya alam yang mencukupi untuk mendukung program otonomi ini akan semakin tertinggal dan mengakibatkan terjadinya ketimpangan kemajuan pendidikan antara daerah yang di kategorikan kaya dan daerah miskin. ${ }^{98}$

3) Pelaksanaan otonomi daerah nyatanya selalu menyebabkan bertambahnya tenaga-tenaga struktural di dalamnya, sehingga terjadi peningkatan jumlah SDM, dan peningkatan jumlah SDM ini pasti akan didikuti dengan peningkatan jumlah anggaran yang harus dikeluarkan untuk operasional pendidikan dengan keterbatasan sumber dana di beberapa daerah dan kurangnya konsep efisiensi dalam penggunannya mengakibatkan permasalahan baru yang terjadi di berbagai daerah. ${ }^{99}$

4) Sistem alokasi anggaran pendidikan di setiap daerah yang berbeda-beda, tergantung dengan selera daerah masing-masing menyebabkan terjadinya ketidakmerataan, ketidakadilan, kurang efisien, kurang efektif, dan membuka pintu terjadinya Korupsi Kolusi dan Nepotisme (KKN), hal ini menjadikan kondisi anggaran pendidikan di beberapa daerah semakin memburuk karena terbatasanya pula anggaran dari pemerintah pusat. $^{100}$

5) Terjadinya penyelewengan pada pengelolaan dan penyaluran dana ke sekolah-sekolah, penyelewengan-penyelewengan tersebut di antaranya adalah : a. adanya pesanan dari pusat soal pengalokasian anggaran pendidikan di daerah, sehingga betentangan dengan prinsip otonomi pendidikan dan berseberangan dengan kebutuhan sekolah dan masyarakat. b. Pendistribusian dana yang kurang proporsional antara sekolah kaya dan sekolah miskin, juga terhadap daerah kaya dan daerah miskin. c. Proses penyaluran dana secara birokratis yang di rasa tidak transparan dan mengakibatkan terbukanya pintu untuk terjadinya KKN. d. Peran pemerintah daerah terhadap proses pembiayaan pendidikan masih sangat minim, jikalaupun ada masih sangat kental dengan kepentingan politik, bukan murni untuk memajukan sektor pendidikan. e. Lemahnya berapa sekolah dalam mengelola anggaran pendidikan di sekolahnya dan kurangnya Oran serta dukungan masyarakat di dalamnya. ${ }^{101}$

6) keterlambatan Pencairan anggaran pendidikan yang tidak sesuai dengan kalender kegiatan pendidikan di masing-masing daerah juga masih menjadi kendala yang tidak kunjung menemukan solusi, hal ini memaksa sekolah untuk menggunakan dana yang

\footnotetext{
98 Suprapti.

99 Suprapti.

100 Suwandi.

101 Suwandi.
} 
harusnya di alokasikan pada kegiatan lain untuk menutup keterlambatan pencairan dana tersebut. ${ }^{102}$

Itulah beberapa permasalahan mengenai pembiayaan pendidikan di era otonomi yang menjadi PR kita semua, khususnya bagi pemerintah pusat dan pemerintah daerah sebagai penangung jawab utama atas program otonomi ini, kita berharap dengan lebih maksimalnya pemanfaatan atas kebiajakan otonomi daerah ini menjadikan pendidikan di Indonesia semakin merata dan berkualitas.

${ }^{102}$ Edy Karno, 'Pemerintah Responsif Pendidikan', Shautut Tarbiyah, November, 2016, 18-38. 


\section{DAFTAR PUSTAKA}

Hartono, 'Otonomi Pendidikan', POTENSIA: Jurnal Kependidikan Islam, 14 (2015), 51-66

Hidayat, Novendra, 'Otonomi Daerah Dan Desentralisasi Pendidikan', Society, VI.35 (2016), 35-49 <http://data4.blog.de/media/285/1849285_62da7ea644_d.pdf>

Karno, Edy, 'Pemerintah Responsif Pendidikan', Shautut Tarbiyah, November, 2016, 18-38

Nadir, Sakinah, 'Otonomi Daerah Dan Desentralisasi Desa', Jurnal Politik Profetik, 1.1 (2013) <https://doi.org/10.24252/jpp.v1i1.1621>

Negeri, Badan Penelitian dan Pengembangan Kementerian Dalam, 'Menelisik Sejarah Otonomi Daerah', Media BPP Kementerian Dalam Negeri, 2017, 1-60

Putra, Roni Eka, and Tengku Rika Valentina, 'Pembiayaan Pendidikan Di Era Otonomi Daerah', Jurnal Demokrasi, IX (2010), 71-92

Safitri, Sani, 'Sejarah Perkembangan Otonomi Daerah Di Indonesia', Jurnal Criksetra, 5.9 (2016), 79-83

Suprapti, 'Analisis Kritis Manajemen Madrasah Di Era Otonomi Daerah', Religi ;Jurnal Studi Islam, 5.April (2014), 102-23

Suwandi, 'Arah Kebijakan Pemanfaatan Dan Penyaluran Dana Pendidikan Pada Era Otonomi Daerah', Jurnal Pendidikan Teknologi Dan Kejuruan, 21.2 (2012), 167-78

Syakdiah, 'Pendanaan Pendidikan Di Indonesia', Jurnal Kebijakan Dan Administrasi Publik, 2005, 109-22

Tolla, Ismail, 'Administrasi Dan Manajemen Pendidikan Dalam Perspektif Otonomi Daerah', Eklektika, 1.1 (2013), 107-18

Toyamah, Nina, and Syaikhu Usman, 'Alokasi Anggaran Pendidikan Di Era Otonomi Daerah: Implikasinya Terhadap Pengelolaan Pelayanan Pendidikan Dasar', Lembaga Penelitian SMERU, 2004, 1-68<http://www.smeru.or.id/id/content/alokasi-anggaranpendidikan-di-era-otonomi-daerah-implikasinya-terhadap-pengelolaan>

Winarsih, Sri, 'Sistem Pembiayaan Pendidikan Dan Otonomi Daerah Dalam Meningkatkan Mutu Pendidikan', Insania, 18.No.2 (2013), 265-86 
Zainuddin, Mohammad, Reformasi Pendidikan Di Era Otonomi Daerah, Kementerian Riset Tekknologi Dan Pendidikan Universitas Negeri Malang, I (malang: kementerian riset, teknologi, dan pendidikan tinggi Universitas Negeri Malang, 2015)

Aqib, Zainal dan Sujak. 2011. Pembiayaan Pendidikan. Jakarta : Gaung Persada Press. Depdiknas, 2009

E. Mulyasa. 2003. Manajemen Berbasis Sekolah : Konsep, Karakteristik, dan Implementas. Bandung : Remaja Rosdakarya.

Fattah. 2006. Ekonomi dan Pembiayaan Pendidikan. Bandung : Remaja Rosdakarya. cetakan keenam.

Harsono. 2007. Pembiayaan Pendidikan. Yogyakarta : Surayajaya Pres.

Martin. 2014. Manajemen. Pembiayaan Pendidikan Konsep dan Aplikasi. Jakarta : Raja Grafindo Persada.

Supriadi, Dedi. 2003. Satuan Biaya Pendidikan. Bandung : Remaja Rosdakarya.

Undang-Undang Sistem Pendidikan nomor 20 tahun 2003.

Zymelman. 1973. Financing and Efficiency in Education: Referent for Administration and Policy Making. Boston the Nimrod Press.

Dedi Supriadi, Satuan Biaya Pendidikan, PT. Remaja Rosdakarya, Bandung, 2004

E. Mulyasa, Manajemen berbasis sekolah, PT Remaja Rosdakarya, Bandung, Mei 2004

Fatah Syukur, Manajemen Pendidikan, PT. Pustaka Rizki Putra, Semarang, 2011

Jamal Ma'mur Asmani, Tips Aplikasi Manajemen Sekolah, Diva Press, Yogyakarta,2010

Nanang Fattah, “Ekonomi Dan Pembiayaan Pendidikan”, Rosdakarya, Bandung, 2004

Nanang Fattah, Landasan Manajemen Pendidikan, PT Remaja Rosdakarya, Bandung, 1996

Udin Syaifudin Sa'ud Dan Abin Syamsuddin Makmun. Perencanaan Pendidikan Suatu Pendekatan Komprensif, Bandung: PT Remaja Rosdakarya. 2007 
Akdon, Dedy Achmad Kurniad. 2017. Manajemen Pembiayaan Pendidikan, Bandung: Remaja Rosdakarya.

Anis, Muhammad Manajemen Pembiayaan Pendidikan di SDIT Assalamah Ungaran, Skripsi.

Arifin, Zaenal. 2010. Evaluasi Pembelajaran, Bandung: Rosdakarya.

Arsyad, Ashar. 2002. Pokok Manajemen, Yogyakarta: Pustaka Pelajar.

Fattah, Nanang. 2000. Ekonomi dan Pembiayaan Pendidikan, Bandung: Remaja Rosdakarya.

Hasbullah, 2010. Otonomi Pendidikan. Jakarta: PT Raja Grafindo Persada.

Jones, Thomas. 1985. Introduction to School Finance: Tecnique and Social Policy, Cambridge, Massachusetts: Ballinger Publishing.

Matin, 2014. Manajemen Pendidikan Konsep dan Aplikasinya. Jakarta: Rapwal Pers.

Morphet, Edgar. 1985. The Economic and Financing of Education, New Jersey: Pergamon Press.

Mulyasa, 2002. Manajemen Berbasis Sekolah. Bandung : PT Remaja Rosdakarya.

Mulyono, 2010. Konsep Pembiayaan Pendidikan. Yogyakarta: Ar-Ruzz Media.

Nawawi, Hadori. 1996. Administrasi Pendidikan, Jakarta: Gunung Agung.

Supriadi, Dedi. 2001. Satuan Biaya Pendidikan SD, SLTP, SMU. Jakarta: Depdiknas.

Undang Undang Dasar RI, 2003. Sistem Pendidikan Nasional (SISDIKNAS), Bandung: Citra Umbara.

Fattah, Nanang, Dr, Ekonomi \& Pembiayaan Pendidikan, (Bandung: PT Remaja Rosdakarya, 2004)

Supriadi Dedi, Prof. Dr. Satuan Biaya Pendidikan Dasar dan Menengah, (Bandung: PT Remaja Rosdakarya, 2004) 
Enoch, Jusuf Prof. Dr. MA. Dasar-Dasar Perencanaan Pendidikan, (Jakarta: Bumi Aksara, 1995)

Tim Pengelola BOS. Buku Panduan Bantuan Operasional Sekolah, (Depdiknas: Dirjen Dikdasmen, 2009)

Peraturan Pemerintah Nomer 48 tahun 2008 tentang Penganggaran Pendidikan

UU No. 20 Tahun 2003 Tentang Sistem Pendidikan Nasional http://asrivixel.blogspot.com/2009/02/buku-pembiayaan-pendidikan.html

Indra Bastian, Akuntansi Pendidikan, (Jakarta: Erlangga, 2007).

Nanang Fattah, Standar Pembiayaan Pendidikan, (Bandung: Remaja Rosdakarya, 2012).

Rida Fironika, Jurnal Volume 02, Nomor 01 Pembiayaan Pendidikan Di Indonesia, http://jurnal.unissula.ac.id/index.php/pendas/article/view/755/632, 18 januari 2016.

Susiana, Tesis Pola Pengelolaan Pembiayaan Madrasah Ibtidaiyah Swasta MIS AlJihad Medan Sunggal, (Medan: Pascasarjana Universitas Negeri Medan, 2016).

Undang-Undang Republik Indonesia tentang Sistem Pendidikan Nasional.

Rahim, Rahmawati, Pola pembiayaan Pendidikan Islam Pada Masa Kalasik, (Palembang, Ta'dib : 01, 2012).

Mulyasa,E, Menajemen Berbasis Sekolah, Bandung : Remaja Rosda Karya, 2004.

Undang-Undang SISDIKNAS 2003, UU RI No. 20 Tahun 2003, Jakarta : Sinar Grafika, 2008.

Asnawir, Administrasi Pendidikan, Padang : IAIN IB Press, 2005.

Ramayulis, Ilmu Pendidikan Islam, Jakarta : Kalam Mulia, 2008.

Munir, Ahmad, Manajemen Pembiayaan Pendidikan Dalam Perspektif Islam, AT-Ta'dib : 02 (2013). 